\title{
EAAT2 as a Research Target in Bipolar Disorder and Unipolar Depression: A Systematic Review
}

\author{
Caren J. Blacker ${ }^{a}$ Vincent Millischer ${ }^{b, e}$ Lauren M. Webb ${ }^{c}$ Ada M.C. Ho ${ }^{d}$ \\ Martin Schalling b, e Mark A. Frye ${ }^{a}$ Marin Veldic $^{a}$ \\ aDepartment of Psychiatry and Psychology, Mayo Clinic Depression Center, Mayo Clinic, Rochester, MN, USA; \\ ${ }^{b}$ Department of Molecular Medicine and Surgery (MMK), Karolinska Institutet, Stockholm, Sweden; 'Mayo Medical \\ School, Mayo Clinic, Rochester, MN, USA; d Department of Molecular Pharmacology and Experimental Therapeutics, \\ Mayo Clinic College of Medicine, Rochester, MN, USA; 'Neurogenetics Unit, Center for Molecular Medicine, \\ Karolinska University Hospital, Stockholm, Sweden
}

\section{Keywords}

Bipolar disorder - Depression - Glutamate - EAAT2 - SCL1A2

\begin{abstract}
Glutamate is implicated in the neuropathology of both major depressive disorder and bipolar disorder. Excitatory amino acid transporter 2 (EAAT2) is the major glutamate transporter in the mammalian brain, removing glutamate from the synaptic cleft and transporting it into glia for recycling. It is thereby the principal regulator of extracellular glutamate levels and prevents neuronal excitotoxicity. EAAT2 is a promising target for elucidating the mechanisms by which the glutamate-glutamine cycle interacts with neuronal systems in mood disorders. Forty EAAT2 studies (published January 1992-January 2018) were identified via a systematic literature search. The studies demonstrated that chronic stress/ steroids were most commonly associated with decreased EAAT2. In rodents, EAAT2 inhibition worsened depressive behaviors. Human EAAT2 expression usually decreased in depression, with some regional brain differences. Fewer data have been collected regarding the roles and regulation of EAAT2 in bipolar disorder. Future directions for research include correlating EAAT2 and glutamate levels in vivo, eluci-
\end{abstract}

dating genetic variability and epigenetic regulation, clarifying intracellular protein and pharmacologic interactions, and examining EAAT2 in different bipolar mood states. As part of a macromolecular complex within glia, EAAT2 may contribute significantly to intracellular signaling, energy regulation, and cellular homeostasis. An enhanced understanding of this system is needed.

(c) 2019 S. Karger AG, Basel

\section{Introduction}

Mood disorders cause a significant burden of disease worldwide. Globally, depression has a prevalence of $4.4 \%$ [1], affecting approximately 322 million people, with significant loss of quality-adjusted life years and productivity, and increased risk of suicide. Bipolar disorder (BD) has an estimated prevalence of up to $4.4 \%$ in the US population [2] and is associated with elevated suicide risk and significant morbidity. Depression and BD are clinically heterogeneous mood disorders which, in mania or severe depression, can present with psychotic symptoms. As the major excitatory neurotransmitter of the mammalian brain, glutamate has been associated with both mood and 
Fig. 1. Representation of roles of EAAT2 in both preventing extracellular glutamate concentrations from reaching neurotoxic levels and in recycling glutamate at synapses, by transporting glutamate into astrocytes for conversion to glutamine. AMPAR, a-amino-3-hydroxy-5-methyl-4-isoazolepropionic acid receptor; AQP4, aquaporin 4; EAAT, excitatory amino acid transporter; Gln, glutamine; Glu, glutamate; KAR, kainate receptor; mGluR, metabotropic glutamate receptor; NMDAR, N-methyl-D-aspartic acid receptor; SAT, system A transporter; SN1, system N transporter.

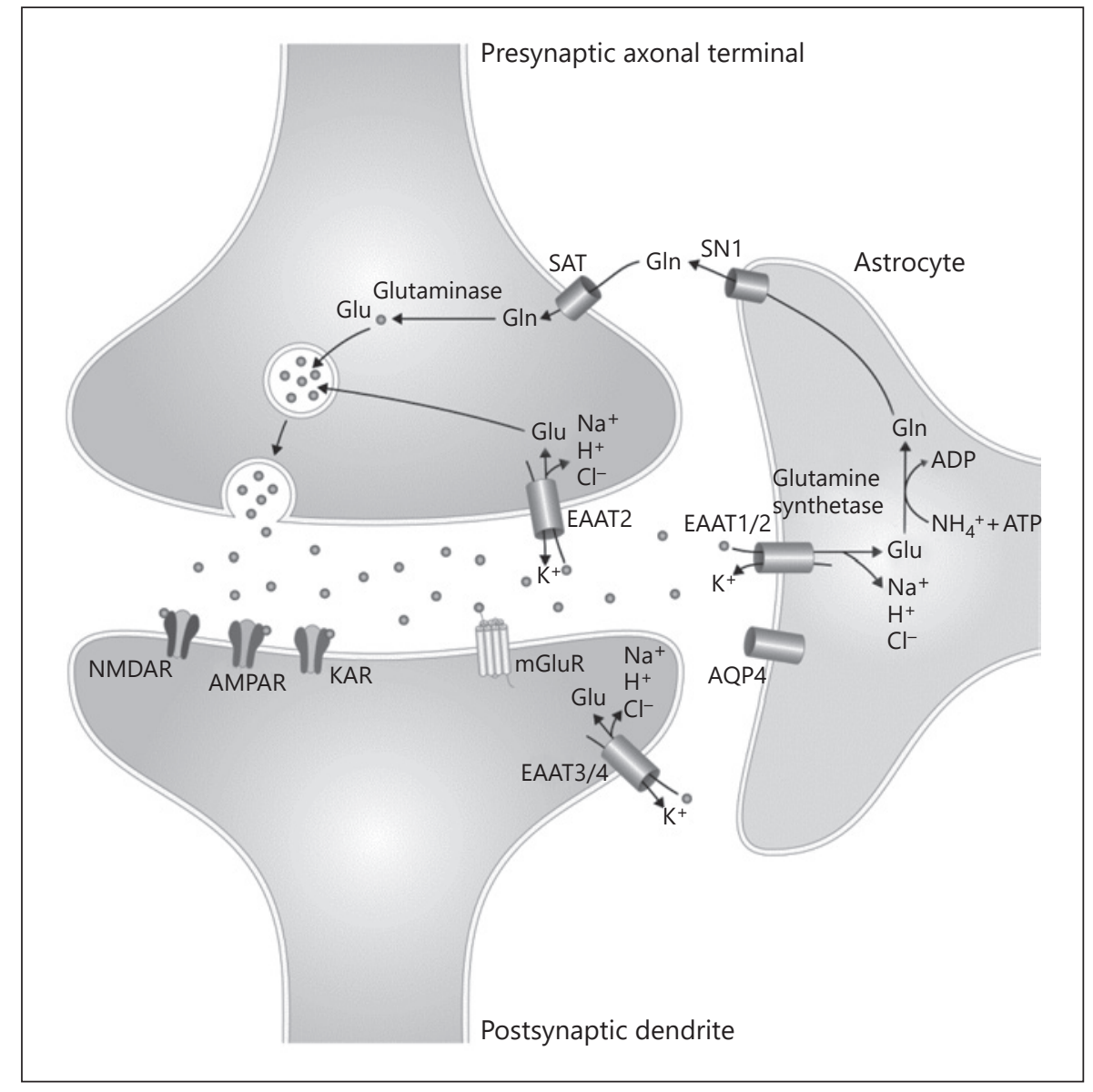

psychotic disorders $[3,4]$. Released by presynaptic neurons, glutamate is transported into surrounding glial cells and recycled back to glutamine. Glutamine is the precursor molecule to both glutamate and $\gamma$-aminobutyric acid (GABA), the major inhibitory neurotransmitter in the central nervous system. This glutamate-glutamine cycle helps regulate neuronal excitability [5].

The main glutamate transporter in the mammalian brain is the excitatory amino acid transporter 2 (EAAT2), also called glutamate transporter 1 (Glt-1) in rodent literature, or solute carrier family 1 member 2 (SLC1A2). It is encoded by the SLC1A2 gene and inhibited by dihydrokainate (DHK) [6]. EAAT2 plays a crucial role in preventing extracellular glutamate concentrations from reaching neurotoxic levels [7] and in recycling glutamate at synapses by transporting glutamate into astrocytes for conversion to glutamine (Fig. 1). This figure also illustrates an overview of the multiple dynamic interactions between glutamate receptors and transporter subtypes within the glutamate cycle. There are five mammalian EAAT isoforms (EAAT1-5) of the solute carrier 1 (SLC1) glutamate transporter family [8]. EAAT isoforms have different tissue localizations, amino acid sequences, and pharmacological profiles. Only EAAT1 (also known as glutamate-aspartate transporter, GLAST) and EAAT2 are expressed in astrocytes. EAAT2 is additionally expressed on axon terminals [9]. EAAT3 is fairly ubiquitously expressed in neuronal tissue, with high intracellular and postsynaptic terminal concentrations, possibly for rapid buffering of local glutamate changes [10].

Glutamate transporters share 25-30\% homology [11], and the structure of EAAT2 is partially extrapolated from homologs. EAAT2 is a bowl-shaped homotrimer with a large central water-filled cavity extending into the cell membrane [12]. Each monomer contains glutamate-binding sites and transport pathways and can probably bind and transport glutamate independently of the other monomers [13]. Each monomer core contains substrate- and ionbinding sites and is comprised of two hairpin loops (HP1, HP2) which may comprise the internal and external gates of the transporter and multiple transmembrane (TM1-8) 
Fig. 2. Flow diagram of Preferred Reporting Items for Systematic Reviews and Meta-Analyses (PRISMA) criteria search strategy for systematic literature review.

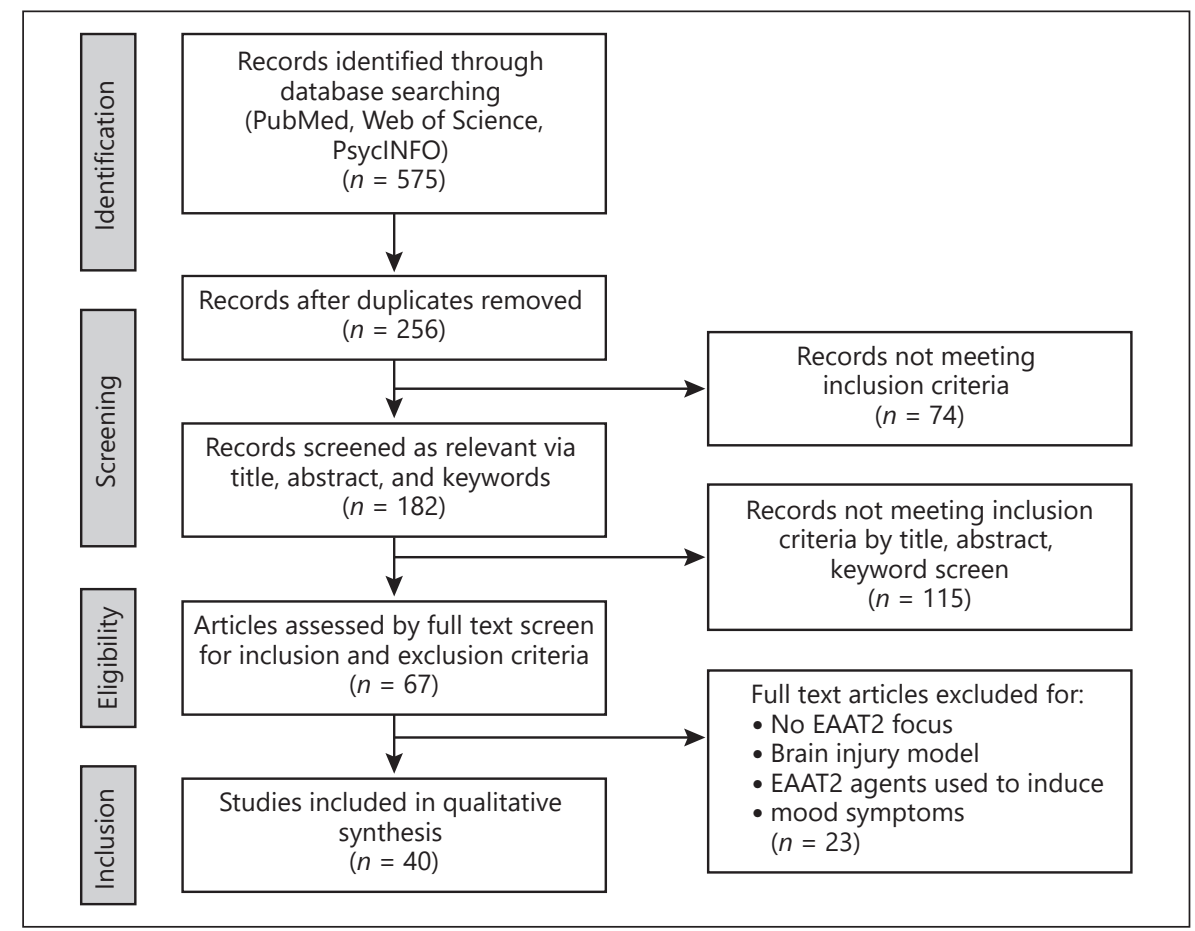

segments. Glutamate and kainate induce distinct conformational changes in the external gate of EAAT2 [14]. EAAT2 is believed to co-transport glutamate with three sodium ions and one hydrogen ion down concentration gradients into the cell, with sequential counter-transport of one potassium ion; each monomer also contains a chloride channel, possibly a feedback system reducing glutamate release [15]. EAAT2 is part of a macromolecular complex that includes aquaporin-4 (AQP4) [16], a water channel that plays a key role in ion and fluid homeostasis within the brain [17]. This complex further includes other membrane proteins, mitochondria, and glycolytic enzymes, suggesting complex regulatory and homeostatic functions [18]. AQP4 may buffer astrocytic water volume affected by EAAT2 activation [19]. AQP4 is of clinical interest in a wide variety of neurological conditions, including neuromyelitis optica, epilepsy, Alzheimer's dementia, traumatic brain injury, and Parkinson's disease.

EAAT2/Glt-1 displays transcript variants [20], and Glt- $1 \mathrm{a}$ and Glt-1b are the most commonly described. The two splice variants have different cellular and subcellular expression profiles [21]. EAAT2 is differentially expressed across anatomical regions in different psychiatric conditions. For example, rodent depression models demonstrate increased hippocampal Glt-1a mRNA/protein, but schizophrenic humans have decreased parahippocampal and dorsolateral prefrontal cortex EAAT2 [7]. Pharmacologic studies also find associations between EAAT2 and neuropsychiatric disorders: riluzole, ceftriaxone, and steroids are medications that alter EAAT2 expression and may have antidepressant effects in rodents [22, 23]. Riluzole is a sodium channel blocker that upregulates EAAT2 protein levels, reduces synaptic glutamate release, and inhibits ionotropic glutamate receptors [22]. Ceftriaxone is a $\beta$-lactam antibiotic which upregulates EAAT2 levels and glial glutamate uptake, and has been investigated for the prevention of alcohol withdrawal [24]. Glucocorticoids cause immediate hippocampal Glt-1 mRNA/protein increases in rodent stress models $[25,26]$, followed by gradual decreases after chronic exposure [22].

The role of EAAT2 in selected disease processes has been summarized previously [8]. This review summarizes the current state of knowledge of the roles of EAAT2 in unipolar and bipolar mood disorders. For precision, we refer to Glt-1 in rodent studies, and EAAT2 in human studies.

\section{Literature Search}

We conducted a comprehensive literature search of PubMed, PsycInfo, and Web of Science from 1 January 1992 [27] through 15 January 2018. Database-specific
Blacker/Millischer/Webb/Ho/Schalling/ Frye/Veldic 
truncations ensured that searches included singulars/plurals and alternate suffixes or spellings. Boolean search string was: Title, Abstract, Keywords/MeSH terms (EAAT2 OR SLC1A2 OR Glt-1 OR "excitatory amino acid transporter" OR "solute carrier family 1 member 2" OR "glutamate transporter 1") AND Title, Abstract, Keywords/MeSH terms: (bipolar OR depress* OR unipolar). Articles were collated in EndNote X8 (Clarivate Analytics, Philadelphia, PA, USA). Duplicates were removed by the software via author, year, title, and journal comparison, and any remaining duplicates were removed manually by first author. Each abstract was reviewed independently by first and final authors. Sixty-seven articles were selected for full text review (Fig. 2).

Literature was eligible for inclusion: (1) if it discussed the roles, functions, interactions, or regulation of EAAT2 in human patients with $\mathrm{BD}$ or unipolar depression, or mammalian models (behavioral, genetic, or pharmacological) of $\mathrm{BD}$ or unipolar depression, or models of molecular interactions in BD or unipolar depression; (2) if the full text was available in English; and (3) if it was published in print or electronically between January 1992 and January 2018. Exclusion criteria were: (1) studies inducing mood symptoms through brain tissue damage (ischemia, surgical resection, etc.); (2) genetic models of non-mood disorder diseases; and (3) in silico models of molecular interactions. Forty articles met all the inclusion criteria. Twenty-six described animal models of depressive or bipolar symptoms [17, 22, 25, 26, 28-47]. Sixteen described human studies of major depressive disorder (MDD) and/ or BD [48-63]. The papers are summarized in Tables 1 and 2. Each experimental paper was reviewed for design, sample size, description and duration of experiment, types of controls, how results were obtained and analyzed, and experimental findings. Data were extracted independently and in duplicate. Studies were appraised for quality using a modification of a published review process [64]; all papers met a quality score of moderate or high.

\section{Findings}

Glt-1 Expression in Animal Models of Mood Disorders

Animal studies frequently model depression via uncontrollable stress (e.g., chronic restraint, territorial intrusions, electric shocks, social isolation, social defeat) to induce learned helplessness and behavioral evidence of despair and anhedonia [29,65]. Acute stress increases synaptic glutamate release and glutamate clearance in the PFC, while chronic stress decreases glutamate receptors,

EAAT2 in Bipolar Disorder and Unipolar Depression reduces glutamate recycling, and alters glutamate regulation [66]. Since stress responses are mediated by the HPA axis, corticosteroid administration is also used to model depression.

\section{Rodent Stress Models of Depression}

Studies of Glt-1 in rodent mood models have produced conflicting results. Earlier studies reported that stress upregulated hippocampal Glt-1 expression $[25,26$, 37], possibly as a neuroprotective response to stress-induced synaptic glutamate increases [39]. Later studies demonstrated that chronic stress downregulated Glt-1 in both rats $[29,32,35,36]$ and mice [37, 42].

In rats, chronic unpredictable stress decreased hippocampal Glt-1 protein without changing EAAT1/GLAST [45]. Chronic stress also significantly decreased hippocampal EAAT2/Glt-1 and EAAT3 protein levels (encoded by $S L C 1 A 2$ and $S L C 1 A 1$, respectively), in addition to associated depressive behaviors [46]. Stress may decrease Glt-1 partially via phosphodiesterases, since the phosphodiesterase 4D inhibitor (GEBR-7b) prevented stressinduced hippocampal Glt-1 protein decreases in rats [36].

Sex-specific effects in Glt-1 expression have also been reported. In stressed rats, compared to controls, females demonstrated reduced Glt-1 protein in the PFC, while males showed reduced Glt- 1 in the striatum [40]. Prenatal stress administered to pregnant rats significantly reduced hippocampal, frontal cortex, and striatum Glt-1 levels in male rat offspring and was associated with increased depressive behaviors $[43,44]$. Female offspring were not assessed. Prenatal stress reduces glial cells in animals and humans, and sex differences in hippocampal glial numbers have been reported, with female offspring in a prenatal stress model demonstrating significant glial reduction, depressed behaviors, and cognitive deficits compared to male offspring [67]. Since Glt-1 is preferentially expressed in glia, it is important to consider whether Glt1 decreases are due to changes in transcription/translation, or to a loss of glial cells expressing Glt-1. Correlating Glt-1 levels and glial numbers across species and between brain regions would help interpret these results.

Strain-specific responses were seen both within mice [37] and rats [41]. Chronic stress increased hippocampal Glt-1 levels in DBA/2J mice (a strain bred for extreme intolerance to alcohol/morphine and susceptibility to seizures) but decreased Glt-1 levels in seizure-resistant C57BL/6J mice and other strains [37]. DBA/2J astrocytes have previously demonstrated much higher rates of GABA synthesis than C57BL/6J and higher glutamate-toGABA ratios [68]. This suggests the distinct Glt-1 stress 
Table 1. Summaries of animal studies included in the systematic analysis

\begin{tabular}{|c|c|c|c|c|c|}
\hline Reference & Description & Species & Tissue examined & Subject characteristics & Findings \\
\hline $\begin{array}{l}\text { Reagan et al. [25], } \\
2004\end{array}$ & $\begin{array}{l}\text { Examine the chronic restraint stress } \\
\text { effect on Glt-1 mRNA and protein } \\
\text { expression in rat hippocampus, and } \\
\text { modulating effect/s of the antidepres- } \\
\text { sant tianeptine }\end{array}$ & $\begin{array}{l}\text { Sprague-Dawley rats, CD } \\
\text { strain }\end{array}$ & Hippocampus & $\begin{array}{l}40 \text { adult male rats: } \\
10 \text { CRS + saline } \\
10 \text { CRS + tianeptine } \\
10 \text { unrestrained + saline } \\
10 \text { unrestrained + tianeptine }\end{array}$ & $\begin{array}{l}\text { Stress increases Glt-1a mRNA and protein in } \\
\text { CA3; tianeptine prevents Glt-1a mRNA increas- } \\
\text { es in CA3; neither stress nor tianeptine alter } \\
\text { Glt-1b mRNA in CA3; stress increases Glt-1b } \\
\text { protein across hippocampus; tianeptine does } \\
\text { not prevent Glt-1b protein increases }\end{array}$ \\
\hline $\begin{array}{l}\text { Wood et al. [26], } \\
2004\end{array}$ & $\begin{array}{l}\text { Measure hippocampal Glt-1 mRNA } \\
\text { expression and neuronal remodeling } \\
\text { in chronic restraint stress models of } \\
\text { depression, and effect of lithium on } \\
\text { Glt-1 expression and histological } \\
\text { findings }\end{array}$ & Sprague-Dawley rats & Hippocampus & $\begin{array}{l}30 \text { adult male rats: } \\
7 \text { CRS + lithium } \\
9 \text { CRS } \\
7 \text { unrestrained + lithium } \\
7 \text { unrestrained }\end{array}$ & $\begin{array}{l}\text { Stress increased Glt-1 mRNA CA3 expression; } \\
\text { lithium prevents this stress-induced Glt-1 } \\
\text { increase; lithium also prevents stress-induced } \\
\text { decrease in CA3 pyramidal apical dendritic } \\
\text { length }\end{array}$ \\
\hline $\begin{array}{l}\text { Bechtholt-Gompf } \\
\text { et al. [28], } 2010\end{array}$ & $\begin{array}{l}\text { Examine the effect of Glt- } 1 \text { inhibition } \\
\text { by DHK on behavioral tests of mood } \\
\text { and cognition }\end{array}$ & Sprague-Dawley rats & $\begin{array}{l}\text { Whole brain coronal } \\
\text { sections for immuno- } \\
\text { histochemistry }\end{array}$ & $\begin{array}{l}73 \text { adult rats; } \\
\text { Immunohistochemistry: } \\
7-8 \text { control } \\
\text { 7-8 DHK } 25.0 \mathrm{nMol} \\
7-8 \text { DHK } 50.0 \mathrm{nMol}\end{array}$ & $\begin{array}{l}\text { DHK inhibition of Glt-1 increases intracranial } \\
\text { self-stimulation; DHK inhibition of Glt-1 does } \\
\text { not change place aversion; DHK inhibition of } \\
\text { Glt-1 induces spatial navigation impairments; } \\
\text { DHK increases c-Fos in reward/mood brain } \\
\text { regions }\end{array}$ \\
\hline $\begin{array}{l}\text { Zink et al. } \\
{[47], 2010}\end{array}$ & $\begin{array}{l}\text { Glutamate transporter expression in } \\
\text { behaviorally characterized lines of } \\
\text { rats with congenital liability to or } \\
\text { resistance to stress-induced helpless- } \\
\text { ness }\end{array}$ & $\begin{array}{l}\text { Sprague-Dawley rats; } \\
\text { subsets inbred for } \\
\text { congenital learned } \\
\text { helplessness }\end{array}$ & $\begin{array}{l}\text { Hippocampus, } \\
\text { occipital cortex }\end{array}$ & $\begin{array}{l}18 \text { male rats: } \\
6 \text { helpless cLH } \\
6 \text { not-helpless cNLH } \\
6 \text { not-helpless cLH }\end{array}$ & $\begin{array}{l}\text { Glt- } 1 \text { mRNA and protein decrease in helpless } \\
\text { cLH cohort }\end{array}$ \\
\hline $\begin{array}{l}\text { Gourley } \\
\text { et al. [22], } \\
2012\end{array}$ & $\begin{array}{l}\text { Effect of riluzole on Glt-1 expression } \\
\text { and behaviors in rodent acute stress } \\
\text { and chronic corticosteroid adminis- } \\
\text { tration }\end{array}$ & C57BL/6 mice & Hippocampus & $\begin{array}{l}28 \text { male mice: } \\
\text { 6: } 6 \mu \mathrm{g} / \mathrm{mL} \text { riluzole } \\
\text { 8:30 } \mu \mathrm{g} / \mathrm{mL} \text { riluzole } \\
\text { 8: } 60 \mu \mathrm{g} / \mathrm{mL} \text { riluzole } \\
\text { 6: control }\end{array}$ & $\begin{array}{l}\text { Corticosteroids reduces Glt-1 protein expres- } \\
\text { sion in hippocampus; riluzole restores steroid- } \\
\text { suppressed protein Glt-1 expression; riluzole } \\
\text { increases Glt-1 protein expression in steroid- } \\
\text { naïve mice; riluzole prevents despair behavior in } \\
\text { forced swim, but not tail suspension }\end{array}$ \\
\hline $\begin{array}{l}\text { Malki et al. [37], } \\
2012\end{array}$ & $\begin{array}{l}\text { RNA expression study in hippocampi } \\
\text { across inbred mouse strains to } \\
\text { evaluate antidepressant effects of nor- } \\
\text { triptyline and escitalopram on gene } \\
\text { expression in chronic stress-induced } \\
\text { (forced swim, maternal separation, } \\
\text { chronic mild stress) models of } \\
\text { depression }\end{array}$ & $\begin{array}{l}4 \text { inbred mouse strains: } \\
\text { C57BL/6J } \\
\text { DBA/2J } \\
129 \mathrm{~S} 1 / \text { SvemJ } \\
\text { FVB/NJ }\end{array}$ & Hippocampus & $\begin{array}{l}72 \text { male and } 72 \text { female mice: } \\
\text { Acute vs. chronic } 4 \mathrm{mg} / \mathrm{kg} \text { escitalopram } \\
+ \text { stress vs. control } \\
\text { Acute vs. chronic } 5 \mathrm{mg} / \mathrm{kg} \text { nortriptyline } \\
+ \text { stress vs. control } \\
\text { Acute vs. chronic control saline + stress } \\
\text { vs. control }\end{array}$ & $\begin{array}{l}\text { SLC1A2 mRNA hippocampal expression } \\
\text { decreased in C57BL/6J, 129S1/SvemJ, FVB/NJ } \\
\text { strains; SLC1A2 mRNA hippocampal expres- } \\
\text { sion increased in DBA/2J strain; escitalopram } \\
\text { and nortriptyline altered SLC1A2 in strain-spe- } \\
\text { cific manner, reversing stress-induced SLC1A2 } \\
\text { mRNA changes in each strain }\end{array}$ \\
\hline $\begin{array}{l}\text { Martisova } \\
\text { et al. [39], } \\
2012\end{array}$ & $\begin{array}{l}\text { Explore the effect of chronic corticos- } \\
\text { terone administration on EAAT2 } \\
\text { hippocampal protein levels }\end{array}$ & Wistar rats & Hippocampus & $\begin{array}{l}\text { 3-month-old male rats: } \\
\text { 6: } 18 \mathrm{mg} / \mathrm{kg} \text { corticosterone } \\
\text { 6: placebo }\end{array}$ & $\begin{array}{l}\text { Corticosterone increased EAAT2 hippocampal } \\
\text { protein expression }\end{array}$ \\
\hline $\begin{array}{l}\text { Zhang et al. } \\
\text { [43], } 2013\end{array}$ & $\begin{array}{l}\text { Examine EAAT2 mRNA expression } \\
\text { in hippocampus, striatum, and } \\
\text { frontal cortex of rat after prenatal } \\
\text { stress }\end{array}$ & Sprague-Dawley rats & $\begin{array}{l}\text { Hippocampus, } \\
\text { striatum, frontal } \\
\text { cortex }\end{array}$ & $\begin{array}{l}18 \text { pregnant female rats: } \\
6 \text { control } \\
6 \text { mid-prenatal stress } \\
6 \text { late-prenatal stress } \\
72 \text { male and female offspring: } \\
4 \text { from each mother }\end{array}$ & $\begin{array}{l}\text { Prenatal stress significantly reduced EAAT2 } \\
\text { mRNA expression in hippocampus, frontal } \\
\text { cortex, and striatum of juvenile offspring, with } \\
\text { associated depressive behavior }\end{array}$ \\
\hline $\begin{array}{l}\text { Chen et al. } \\
{[29], 2014}\end{array}$ & $\begin{array}{l}\text { Evaluate the effects of chronic } \\
\text { unpredictable stress and } 10 \mathrm{mg} / \mathrm{kg} \\
\text { fluoxetine on depressive behaviors in } \\
\text { rats and Glt-1 protein levels in rat } \\
\text { hippocampus }\end{array}$ & Sprague-Dawley rats & Hippocampus & $\begin{array}{l}60 \text { male rats: } \\
20 \text { control + saline } \\
20 \text { CUS + saline } \\
20 \text { CUS + fluoxetine }\end{array}$ & $\begin{array}{l}\text { CUS associated with depressive behaviors, and } \\
\text { decreased Glt-1 protein; fluoxetine reversed } \\
\text { both }\end{array}$ \\
\hline $\begin{array}{l}\text { Cui et al. } \\
{[30], 2014}\end{array}$ & $\begin{array}{l}\text { DHK and genetic inhibition of Glt-1 } \\
\text { transporter in mouse LHb, testing for } \\
\text { LHb neuronal activity, behavioral } \\
\text { response (with and without } 20 \mathrm{mg} / \mathrm{kg} \\
\text { fluoxetine), and sleep EEG/EMG }\end{array}$ & $\begin{array}{l}\text { C57BL/6J mice } \\
\text { Floxed Glt-1 } \\
\text { mice }\end{array}$ & Lateral habenula & $\begin{array}{l}\text { Male mice: } \\
51 \text { control } \\
46 \text { lateral habenula Glt-1 knockout } \\
\text { (floxed) }\end{array}$ & $\begin{array}{l}\text { Glt-1 inhibition increased excitability in LHb; } \\
\text { Glt-1 inhibition displayed worse depressive } \\
\text { behavior and increased susceptibility to chronic } \\
\text { stress; Glt-1 inhibition had disinhibited REM } \\
\text { sleep; fluoxetine improved depressive behavior } \\
\text { on tail suspension despite Glt-1 inhibition }\end{array}$ \\
\hline $\begin{array}{l}\text { Kong et al. } \\
{[17], 2014}\end{array}$ & $\begin{array}{l}\text { AQP4 wild-type vs. knockout mice } \\
\text { administered chronic corticosterone, } \\
\text { EAAT1 and EAAT2 hippocampal } \\
\text { protein expression evaluated }\end{array}$ & CD1 mice & $\begin{array}{l}\text { Hippocampus, } \\
\text { Dentate gyrus }\end{array}$ & $\begin{array}{l}\text { Male mice: } \\
5 \mathrm{AQP} 4+/+ \\
5 \mathrm{AQP}-/- \\
\text { Corticosterone } 20 \mathrm{mg} / \mathrm{kg} \text { once daily } \\
\text { subcutaneously }\end{array}$ & $\begin{array}{l}\text { AQP4 knockout mice had exacerbated depres- } \\
\text { sive behaviors; corticosterone inhibited hippo- } \\
\text { campal EAAT2 protein expression only in } \\
\text { AQP-/- mice; corticosterone inhibited hippo- } \\
\text { campal EAAT1 protein expression in both } \\
\text { wild-type and knockout mice }\end{array}$ \\
\hline $\begin{array}{l}\text { Veeraiah } \\
\text { et al. [42], } \\
2014\end{array}$ & $\begin{array}{l}\text { Mice exposed to chronic social defeat } \\
\text { to induce depressive phenotype, } \\
\text { subsequent evaluation of sucrose } \\
\text { preference, social interaction, and } \\
\text { prefrontal cortex markers including } \\
\text { EAAT2 mRNA }\end{array}$ & C57BL/6 mice & Prefrontal cortex & $\begin{array}{l}\text { Male mice: } \\
15 \text { control } \\
30 \text { social defeat paradigm }\end{array}$ & $\begin{array}{l}\text { EAAT2 mRNA levels significantly lower in PFC } \\
\text { of depressed mice }\end{array}$ \\
\hline $\begin{array}{l}\text { John et al. } \\
{[33], 2015}\end{array}$ & $\begin{array}{l}\text { DHK blockade of Glt-1 in the } \\
\text { amygdala assessed by ICSS (as an } \\
\text { index of hedonia and anxious } \\
\text { behavior) and behavior tests }\end{array}$ & Sprague-Dawley rats & $\begin{array}{l}\text { Central nucleus of } \\
\text { amygdala }\end{array}$ & $\begin{array}{l}\text { Male rats: } \\
8 \text { control PBS } \\
\text { 8: } 1.563 \mathrm{nM} \text { intra-CEA-DHK infusion } \\
\text { 8: } 3.125 \mathrm{nM} \text { intra-CEA-DHK infusion } \\
\text { 8: } 6.25 \mathrm{nM} \text { intra-CEA-DHK infusion } \\
\text { 8: } 9.375 \mathrm{nM} \text { intra-CEA-DHK infusion } \\
\text { 8: } 12.5 \mathrm{nM} \text { intra-CEA-DHK infusion }\end{array}$ & $\begin{array}{l}\text { Amygdala Glt-1 inhibition by DHK induces } \\
\text { anxiety and anhedonic/ } \\
\text { depressive behaviors }\end{array}$ \\
\hline
\end{tabular}


Table 1 (continued)

\begin{tabular}{|c|c|c|c|c|c|}
\hline Reference & Description & Species & Tissue examined & Subject characteristics & Findings \\
\hline $\begin{array}{l}\text { Réus et al. } \\
\text { [41], } 2015\end{array}$ & $\begin{array}{l}\text { Examine chronic mild stress in high } \\
\text { and low anxious phenotype rats: } \\
\text { effect on DNA damage, NMDA, and } \\
\text { Glt-1 levels in PFC, hippocampus, } \\
\text { amygdala, and NA }\end{array}$ & $\begin{array}{l}\text { Carioca High-Freezing } \\
\text { rats } \\
\text { Carioca Low-Freezing } \\
\text { rats } \\
\text { Albino Wistar } \\
\text { rats as controls }\end{array}$ & $\begin{array}{l}\text { Prefrontal cortex, } \\
\text { hippocampus, } \\
\text { amygdala, nucleus } \\
\text { accumbens }\end{array}$ & $\begin{array}{l}\text { 6 groups: } \\
\text { Wistar + control conditions } \\
\text { Wistar + stress } \\
\text { CLF + control conditions } \\
\text { CLF + stress } \\
\text { CHF + control conditions } \\
\text { CHF + stress }\end{array}$ & $\begin{array}{l}\text { EAAT2 decreased in PFC of stressed Wistars } \\
\text { relative to unstressed Wistars; EAAT2 increased } \\
\text { in PFC of unstressed CHF relative to unstressed } \\
\text { Wistars; EAAT2 increased in hippocampus of } \\
\text { unstressed CLF relative to unstressed Wistars; } \\
\text { EAAT2 decreased in hippocampus of stressed } \\
\text { CLF relative to unstressed CLF; EAAT2 de- } \\
\text { creased in amygdala of stressed CLF relative to } \\
\text { unstressed Wistars; EAAT2 decreased in } \\
\text { amygdala of stressed CHF relative to unstressed } \\
\text { Wistars; EAAT2 did not change in NA of any } \\
\text { group relative to control }\end{array}$ \\
\hline
\end{tabular}

\begin{tabular}{|c|c|c|c|c|c|}
\hline $\begin{array}{l}\text { Zhu et al. } \\
\text { [45], } 2015\end{array}$ & $\begin{array}{l}\text { Examine the effect of propofol and } \\
\text { ECS on glutamate uptake, and } \\
\text { EAAT1/2 protein levels, in rats } \\
\text { depressed through chronic unpre- } \\
\text { dictable mild stress }\end{array}$ & Sprague-Dawley rats & Hippocampus & $\begin{array}{l}60 \text { adult rats: } \\
12 \text { control } \\
12 \text { CUMS + sham ECS } \\
12 \text { CUMS + ECS } \\
12 \text { CUMS + propofol } \\
12 \text { CUMS + propofol + ECS }\end{array}$ & $\begin{array}{l}\text { GLAST/EAAT1 protein showed no differences } \\
\text { between groups; Glt-1 protein was significantly } \\
\text { higher in control than other four groups; Glt-1 } \\
\text { protein was significantly lower in CUMS + ECS; } \\
\text { propofol significantly increased Glt-1 protein } \\
\text { levels }\end{array}$ \\
\hline $\begin{array}{l}\text { Gómez-Galán et al. } \\
\text { [32], 2016 }\end{array}$ & $\begin{array}{l}\text { Genetic depression model in rats sub- } \\
\text { jected to social isolation to assess } \\
\text { molecular effects, then assessed for } \\
\text { effects of physical exercise on social } \\
\text { isolation-induced molecular effects }\end{array}$ & $\begin{array}{l}\text { FSL rats } \\
\text { Sprague-Dawley rats }\end{array}$ & Hippocampus & $\begin{array}{l}\text { Rats: } \\
7 \text { of each strain: group-housed } \\
7 \text { of each strain: social isolation } \\
7 \text { of each strain: social isolation with } \\
\text { exercise }\end{array}$ & $\begin{array}{l}\text { Social isolation decreased Glt-1 protein levels; } \\
\text { exercise reversed the social isolation-induced } \\
\text { Glt-1 protein decrease }\end{array}$ \\
\hline $\begin{array}{l}\text { Liu et al. } \\
{[35], 2016 a}\end{array}$ & $\begin{array}{l}\text { Examine the effect of K252a (a TrkB } \\
\text { receptor inhibitor) to examine } \\
\text { whether BDNF-TrkB signaling is part } \\
\text { of the antidepressant effect of } \\
\text { ketamine in a chronic unpredictable } \\
\text { stress model of depression in rats }\end{array}$ & Sprague-Dawley rats & Hippocampus & $\begin{array}{l}\text { Male rats: } \\
\text { Control + vehicle } \\
\text { CUS + vehicle } \\
\text { CUS + ketamine }(10 \mathrm{mg} / \mathrm{kg}) \\
\text { CUS + K252a }(1 \mu \mathrm{L}, 2 \mathrm{mM})+\text { ketamine } \\
(10 \mathrm{mg} / \mathrm{kg})\end{array}$ & $\begin{array}{l}\text { CUS decreased hippocampal Glt-1 protein } \\
\text { expression; ketamine significantly attenuated } \\
\text { this reduction; K252a pretreatment antagonized } \\
\text { the effects of ketamine }\end{array}$ \\
\hline $\begin{array}{l}\text { Liu et al. } \\
{[36], 2016 b}\end{array}$ & $\begin{array}{l}\text { Examine the effect of GEBR-7b (a } \\
\text { phosphodiesterase } 4 \text { D inhibitor) on } \\
\text { chronically stressed rats as measured } \\
\text { behaviorally and by Glt-1 protein } \\
\text { levels }\end{array}$ & Sprague-Dawley rats & Hippocampus & $\begin{array}{l}\text { Adult male rats: } \\
8 \text { nonstressed + vehicle } \\
8 \text { CUS + vehicle } \\
8 \text { CUS + GEBR-7b }(0.05 \mathrm{mg} / \\
\mathrm{kg})\end{array}$ & $\begin{array}{l}\text { CUS decreased rat exploration and movement } \\
\text { velocity; CUS decreased hippocampal Glt-1 } \\
\text { protein expression; GEBR-7b significantly } \\
\text { reversed this reduction }\end{array}$ \\
\hline $\begin{array}{l}\text { Manosso } \\
\text { et al. [38], } \\
2016\end{array}$ & $\begin{array}{l}\text { Examine the effect of } 10 \mathrm{mg} / \mathrm{kg} \text { zinc } \\
\text { and } 10 \mathrm{mg} / \mathrm{kg} \text { fluoxetine on chronic } \\
\text { unpredictable stress-induced depres- } \\
\text { sive behaviors and synaptic molecules } \\
\text { in mice }\end{array}$ & Swiss mice & Hippocampus & $\begin{array}{l}\text { Female mice: } \\
\text { Nonstressed }+ \text { vehicle } \\
\text { Nonstressed }+\mathrm{ZnCl} 2 \\
\text { Nonstressed }+ \text { fluoxetine } \\
\text { Stressed }+ \text { vehicle } \\
\text { Stressed }+\mathrm{ZnCl} 2 \\
\text { Stressed + fluoxetine }\end{array}$ & $\begin{array}{l}\text { CUS increased immobility in tail suspension } \\
\text { test; zinc chloride prevented CUS-induced } \\
\text { depressive behavior; fluoxetine prevented } \\
\text { CUS-induced depressive behavior; no changes } \\
\text { in hippocampal Glt-1 protein expression in any } \\
\text { experimental group }\end{array}$ \\
\hline $\begin{array}{l}\text { Rappeneau et al. } \\
{[40], 2016}\end{array}$ & $\begin{array}{l}\text { Effect of chronic social defeat stress } \\
\text { on depressive phenotype and } \\
\text { glutamate-glutamine cycle, with sex } \\
\text { effect }\end{array}$ & Long-Evans rats & $\begin{array}{l}\text { Prefrontal cortex, } \\
\text { dorsal striatum, } \\
\text { nucleus accumbens }\end{array}$ & $\begin{array}{l}51 \text { male and } 72 \text { female adult Long-Evans } \\
\text { rats: } \\
\text { Female nonstressed } \\
\text { Female stressed } \\
\text { Male nonstressed } \\
\text { Male stressed }\end{array}$ & $\begin{array}{l}\text { CSDS reduced Glt-1 protein levels in female } \\
\text { PFC; CSDS reduced Glt-1 protein levels in male } \\
\text { striatum }\end{array}$ \\
\hline $\begin{array}{l}\text { Gasull-Camós } \\
\text { et al. [31], } \\
2017\end{array}$ & $\begin{array}{l}\text { Investigate the behavioral and } \\
\text { molecular effects in rats of: DHK } \\
\text { (Glt-1 blocker), veratridine (nonspe- } \\
\text { cific depolarizing agent), NBQX } \\
\text { (AMPA antagonist), s-AMPA } \\
\text { (AMPA agonist), citalopram, and } \\
\text { pCPA (5-HT synthesis inhibitor) }\end{array}$ & Wistar rats & $\begin{array}{l}\text { DHK Glt-1 blockade } \\
\text { of: infralimbic cortex, } \\
\text { prelimbic cortex }\end{array}$ & $\begin{array}{l}\text { Male rats: } \\
\text { Infralimbic infusion of vehicle } \\
\text { Infralimbic infusion of DHK or veratri- } \\
\text { dine or NBQX or s-AMPA or citalo- } \\
\text { pram } \\
\text { Intraperitoneal infusion of pCPA } \\
\text { Prelimbic infusion of vehicle } \\
\text { Prelimbic infusion of DHK or veratri- } \\
\text { dine or NBQX or s-AMPA or citalo- } \\
\text { pram } \\
\text { Intraperitoneal infusion of pCPA }\end{array}$ & $\begin{array}{l}\text { DHK infusion to infralimbic cortex induced } \\
\text { behavioral antidepressant response; DHK } \\
\text { infusion to prelimbic cortex induced no } \\
\text { behavioral response; veratridine infusion to } \\
\text { infralimbic cortex induced rapid behavioral } \\
\text { antidepressant response; veratridine infusion to } \\
\text { prelimbic cortex induced no behavioral change; } \\
\text { DHK-induced antidepressant response: pre- } \\
\text { vented by NBQX and pCPA, mimicked by } \\
\text { s-AMPA and citalopram }\end{array}$ \\
\hline $\begin{array}{l}\text { Zhang et al. } \\
\text { [44], } 2017\end{array}$ & $\begin{array}{l}\text { Effect of icariin on behavior and } \\
\text { glutamate system in prenatally } \\
\text { stressed male rats }\end{array}$ & Sprague-Dawley rats & Hippocampus & $\begin{array}{l}\text { Pregnant female rats: } \\
\text { CRS vs. control } \\
2 \text { male offspring from each mother: } \\
8 \text { control } \\
8 \text { prenatal stress } \\
8 \text { PRS + saline } \\
8 \text { PRS + icariin } 80 \mathrm{mg} / \mathrm{kg} \\
8 \text { PRS + icariin } 40 \mathrm{mg} / \mathrm{kg}\end{array}$ & $\begin{array}{l}\text { Prenatal stress decreased EAAT2 protein } \\
\text { expression in male offspring; prenatal stress } \\
\text { increased mGluR1 and mGluR5 protein } \\
\text { expression in male offspring; prenatal stress } \\
\text { offspring displayed decreased sucrose prefer- } \\
\text { ence, increased immobility; chronic postnatal } \\
\text { icariin administration increased sucrose } \\
\text { preference, reduced immobility time; chronic } \\
\text { postnatal icariin administration increased } \\
\text { EAAT2, and decreased mGluR1/mGluR5 } \\
\text { protein levels }\end{array}$ \\
\hline $\begin{array}{l}\text { Zhu et al. } \\
{[46], 2017}\end{array}$ & $\begin{array}{l}\text { Assess the effect of subanesthetic } \\
\text { doses of ketamine on depressed } \\
\text { behavior and glutamate transporter } \\
\text { hippocampal expression in a stress } \\
\text { model of depression }\end{array}$ & Sprague-Dawley rats & Hippocampus & $\begin{array}{l}60 \text { adult male rats: } \\
12 \text { control } \\
12 \text { CUMS + saline } \\
12 \text { CUMS }+10 \mathrm{mg} / \mathrm{kg} \text { ketamine } \\
12 \text { CUMS }+25 \mathrm{mg} / \mathrm{kg} \text { ketamine } \\
12 \text { CUMS }+50 \mathrm{mg} / \mathrm{kg} \text { ketamine }\end{array}$ & $\begin{array}{l}\text { CUMS significantly downregulated EAAT2/3 } \\
\text { hippocampal protein levels; ketamine reversed } \\
\text { CUMS-induced decreases in EAAT2/3; } \\
\text { CUMS decreased sucrose preference, locomo- } \\
\text { tion, exploratory behavior; ketamine reversed } \\
\text { CUMS-induced behaviors; CUMS increased } \\
\text { extracellular hippocampal glutamate concentra- } \\
\text { tions; ketamine reduced CUMS-induced } \\
\text { hippocampal glutamate concentrations }\end{array}$ \\
\hline
\end{tabular}


Table 1 (continued)

\begin{tabular}{|c|c|c|c|c|c|}
\hline Reference & Description & Species & Tissue examined & Subject characteristics & Findings \\
\hline $\begin{array}{l}\text { Kang et al. } \\
{[34], 2018}\end{array}$ & $\begin{array}{l}\text { Explore the correlation between Glt-1 } \\
\text { function, LHb activity, and alcohol } \\
\text { withdrawal behaviors }\end{array}$ & Sprague-Dawley rats & Lateral habenula & $\begin{array}{l}112 \text { male rats: } \\
10 \text { days intraperitoneal saline } \\
10 \text { days intraperitoneal ethanol }(2 \mathrm{~g} / \mathrm{kg}) \\
10 \text { days intraperitoneal ethanol + last } 5 \\
\text { days ceftriaxone }(200 \mathrm{mg} / \mathrm{kg} / \text { day })\end{array}$ & $\begin{array}{l}\text { Glt-1 protein levels reduced in LHb of alcohol- } \\
\text { withdrawal rats; } \\
\text { Glt-1 protein levels normalized in LHb of } \\
\text { alcohol -withdrawal rats by ceftriaxone; alcohol- } \\
\text { withdrawal rats have higher depressive and } \\
\text { anxious behaviors - these are reversed by } \\
\text { ceftriaxone, and restored by DHK blockade of } \\
\text { Glt-1 }\end{array}$ \\
\hline
\end{tabular}

AQP4, aquaporin-4; CA3, cornu ammonis subregion 3; CEA, central amygdala; CRS, chronic restraint stress; CHF, Carioca High-Freezing rats; CLF, Carioca Low-Freezing rats; cLH, congenital learned helpless; cNLH, congenital not-learned helpless; CSDS, chronic social defeat stress; CUMS, chronic unpredictable mild stress; CUS, chronic unpredictable stress; DHK, dihydrokainic acid; ECS, electroconvulsive shock; EEG, electroencephalogram; EMG, electromyogram; FSL, Flinders sensitive line; ICSS, intracranial self-stimulation; LHb, lateral habenula; NA, nucleus accumbens; PFC, prefrontal cortex.

may be related to an underlying difference in the glutamate/glutamine/GABA system, though it remains unclear whether this involves altered gene transcription, protein expression, transport activity, or GABA synthesis. Different Glt-1 responses to stress have also been seen in rats [41]. Rats bred for helpless behavioral responses to chronic stress were examined within strain, to see whether they displayed helplessness or stress resistance. Their behavior was also compared to that of control rats [47]. The stress-susceptible/behaviorally resilient strain and the control rats retained higher levels of Glt-1, while the stress-susceptible/behaviorally helpless strain had decreased Glt-1 mRNA/protein. Reduced astroglial glutamate uptake and increased glutamate levels were seen in these genetically and behaviorally helpless rats.

\section{Pharmacological Models of Depression and Glt-1}

Modulation

Chronic corticosteroid administration induced depressive behaviors in rodents $[17,22,39]$. In rats, corticosterone treatment increased hippocampal Glt-1 [39]. In mice, steroids reduced hippocampal BDNF and GLAST, glial neurotrophic factor, and neurogenesis in mice, but did not significantly change Glt-1 [17, 22]. However, in AQP4 knockout mice, $20 \mathrm{mg} / \mathrm{kg}$ corticosterone daily for 21 days significantly downregulated Glt-1 protein [17]. Differences in Glt-1 expression within these mouse strains may reflect an effect of AQP4 function. AQP4 knockouts have a reduction in astrocyte number and greater astrocytic vulnerability to steroid-induced injury [17]; their loss could account for the Glt-1 protein level decrease.

In mouse models of steroid-induced depression, riluzole reversed steroid-induced hippocampal Glt-1 suppression and prevented despair behaviors [22], while increasing Glt-1 hippocampal protein in controls. Exercise also reversed social isolation-induced hippocampal Glt-1 protein decrease in rats [32]. A complex study of the mo- lecular and behavioral effects of alcohol withdrawal in rats found that depressive and anxious behaviors could be reversed by ceftriaxone (which upregulates EAAT2 [24]), but they reappeared after DHK treatment [34]. Alcohol withdrawal was associated with significant Glt-1 protein reduction in lateral habenula, which was normalized by ceftriaxone.

Four papers examined the behavioral and molecular consequences of Glt-1 inhibition in rodents [28, 30, 31, 33]. DHK is a specific Glt-1 inhibitor [6]. In SpragueDawley rats, DHK infusion to the lateral ventricles [28] and amygdala [33] resulted in anhedonic/dysphoric behaviors as measured by intracranial self-stimulation. DHK infusion increased c-Fos (a proto-oncogene expressed by neurons after depolarization, and a proxy for neuronal activity) in reward and mood brain regions, including the nucleus accumbens, amygdala, and infralimbic cortex [28]. Mice with acute Glt-1 inhibition (via DHK) and chronic Glt-1 inhibition (floxed Glt-1 knockout) displayed depressive behaviors, reduced resilience to chronic stress, and sleep changes, with increased excitability of their lateral habenula neurons, which are typically activated by unpleasant stimuli [30]. In Wistar rats, DHK infusion to the infralimbic cortex prevented depression-like behavioral responses in stressful scenarios, though DHK had no effect when administered to the prelimbic cortex [31]. The infralimbic result differs from previously reported DHK-induced depressive behaviors. It is unclear whether the difference is related to strain differences between Sprague-Dawley and Wistar rats, or Glt-1 function in the infralimbic cortex. Although DHK is a specific inhibitor of Glt-1 and therefore acts on the glutamate system, the same study found that its antidepressant effect was prevented by serotonin depletion and AMPA glutamate receptor antagonism, while an antidepressant response was seen with the AMPA agonist (sAMPA). These results probably reflect the complex interplay of multiple neurotransmitter systems in depression 
Table 2. Summaries of human studies included in the systematic analysis

\begin{tabular}{|c|c|c|c|c|}
\hline Reference & Description & Subject characteristics & Tissue examined & Findings \\
\hline $\begin{array}{l}\text { McCullumsmith } \\
\text { et al. [54], 2002 }\end{array}$ & $\begin{array}{l}\text { In situ hybridization of } \\
\text { EAAT1/2/3/4 mRNA in postmor- } \\
\text { tem brains of patients with SZ, BD, } \\
\text { MDD, and controls }\end{array}$ & $\begin{array}{l}60 \text { postmortem brains: } \\
15 \mathrm{SZ}(9 \mathrm{M} / 6 \mathrm{~F} ; \mathrm{pH} 6.1 \text { [5.8-6.6]; age } 44.2 \\
\text { [25-62]) } \\
15 \mathrm{BD}(9 \mathrm{M} / 6 \mathrm{~F} ; \mathrm{pH} 6.2 \text { [5.8-6.5]; age } 42.3 \\
[25-61]) \\
15 \mathrm{MDD}(9 \mathrm{M} / 6 \mathrm{~F} ; \mathrm{pH} 6.2,[5.6-6.5] \text {; age } \\
46.4[30-65]) \\
15 \text { control }(9 \mathrm{M} / 6 \mathrm{~F} ; \mathrm{pH} 6.3 \text { [5.8-6.6]; age } \\
48.1[29-68]) \\
56 \text { Caucasian, } 2 \text { Asian, } \\
2 \text { African-American }\end{array}$ & $\begin{array}{l}\text { Striatal tissue: } \\
\text { Caudate } \\
\text { Putamen } \\
\text { Ventral striatum }\end{array}$ & $\begin{array}{l}\text { EAAT1/2/3/4 mRNA was expressed in all striatal tissues; } \\
\text { significantly lower EAAT1 mRNA levels in MDD com- } \\
\text { pared to SZ; significantly lower EAAT3 mRNA levels in } \\
\text { BD/SZ compared to controls; significantly lower EAAT4 } \\
\text { mRNA levels in BD/MDD compared to controls; signifi- } \\
\text { cantly lower EAAT2 mRNA levels in ventral striatum than } \\
\text { caudate/putamen across all diagnoses and controls; } \\
\text { insufficient sample sizes to analyze effect of medications }\end{array}$ \\
\hline $\begin{array}{l}\text { Choudary et al. } \\
{[50], 2005}\end{array}$ & $\begin{array}{l}\text { RNA extracted from postmortem } \\
\text { brains of patients with BD, MDD, } \\
\text { and controls for microarray analysis } \\
\text { and in situ hybridization }\end{array}$ & $\begin{array}{l}22 \text { postmortem brains: } \\
7 \text { control (1 F/6 M; pH } 7.0 \pm 0.1 \text {; age } \\
50 \pm 16.7) \\
9 \mathrm{MDD}(2 \mathrm{~F} / 7 \mathrm{M} ; \mathrm{pH} 6.98 \pm 0.1 ; 48.0 \pm 14.2) \\
6 \mathrm{BD}(1 \mathrm{~F} / 5 \mathrm{M} ; \mathrm{pH} 6.97 \pm 0.1 ; 47.5 \pm 18.7)\end{array}$ & $\begin{array}{l}\text { Left DLPFC (BA9 and } 46) \\
\text { Anterior cingulate gyrus } \\
\text { (BA24) }\end{array}$ & $\begin{array}{l}\text { EAAT2 mRNA expression was significantly decreased in } \\
\text { AnCg and DLPFC in MDD compared to controls; EAAT2 } \\
\text { mRNA levels were higher in AnCg than DLPFC in } \\
\text { controls, BD, and MDD; EAAT1 mRNA expression } \\
\text { decreased in AnCg and DLPFC in MDD compared to } \\
\text { controls }\end{array}$ \\
\hline $\begin{array}{l}\text { Shao et al. [62], } \\
2008\end{array}$ & $\begin{array}{l}\text { RNA extracted from postmortem } \\
\text { brains of patients with BD, SZ, and } \\
\text { controls for microarray analysis, } \\
\text { with PCR validation of candidate } \\
\text { genes; effects of age, sex, and pH } \\
\text { controlled for by ANCOVA }\end{array}$ & $\begin{array}{l}105 \text { postmortem brains: } \\
35 \mathrm{SZ}(23 \mathrm{M} / 9 \mathrm{~F} ; \mathrm{pH} 6.48 \pm 0.25 \text {; age } \\
42.9 \pm 8.6) \\
35 \mathrm{BD}(15 \mathrm{M} / 12 \mathrm{~F} ; \mathrm{pH} 6.5 \pm 0.23 \text {; age } \\
45.3 \pm 9.8) \\
35 \text { control }(23 \mathrm{M} / 6 \mathrm{~F} ; \mathrm{pH} 6.64 \pm 0.26 \text {; age } \\
44.4 \pm 6.5)\end{array}$ & DLPFC (BA46) & $\begin{array}{l}\text { ANCOVA adjusted for } \mathrm{pH} \text { and age, and restricted to } \\
\text { above-median pH and adjusted for } \mathrm{pH} \text { and age, both } \\
\text { suggested enrichment of shared genes between } \mathrm{BD} \text { and } \mathrm{SZ} \text {; } \\
\text { EAAT2 significantly elevated in } \mathrm{BD} \text { and } \mathrm{SZ} \text { on microarray; } \\
\text { EAAT2a (alternatively spliced exon) targeted in qPCR } \\
\text { validation but did not validate, unclear whether due to } \\
\text { targeting wrong region of gene; EAAT2 significantly } \\
\text { increased in proportion to lifetime antipsychotic exposure } \\
\text { (fluphenazine equivalents) }\end{array}$ \\
\hline $\begin{array}{l}\text { Miguel-Hidalgo } \\
\text { et al. [57], } 2010\end{array}$ & $\begin{array}{l}\text { Comparison of EAAT2 protein } \\
\text { levels across cortical layers in left } \\
\text { orbitofrontal cortex of postmortem } \\
\text { patients with major depression, } \\
\text { alcohol use disorder, major depres- } \\
\text { sion + alcohol use disorder, and } \\
\text { controls }\end{array}$ & $\begin{array}{l}49 \text { postmortem brains: } \\
13 \mathrm{MDD}(9 \mathrm{M} / 4 \mathrm{~F} ; \mathrm{pH} 6.65 \pm 0.18 \text {; age } \\
48.54 \pm 19.89) \\
10 \mathrm{MDD}+\mathrm{ALC}(4 \mathrm{M} / 6 \mathrm{~F} ; \mathrm{pH} 6.61 \pm 0.23 \text {; } \\
\text { age } 50.50 \pm 13.20) \\
13 \mathrm{AD}(11 \mathrm{M} / 2 \mathrm{~F} ; \mathrm{pH} 6.66 \pm 0.16 \text {; age } \\
48.08 \pm 14.17) \\
13 \text { control }(6 \mathrm{M} / 7 \mathrm{~F} ; \mathrm{pH} 6.43 \pm 0.40 \text {; age } \\
51.15 \pm 14.44)\end{array}$ & $\begin{array}{l}\text { Left orbitofrontal cortex } \\
\text { (BA47) }\end{array}$ & $\begin{array}{l}\text { EAAT2 protein levels significantly lower in MDD and } \\
\text { MDD+ALC than controls; EAAT1 protein levels lower in } \\
\text { MDD and MDD+ALC than controls; EAAT2 immunos- } \\
\text { taining highest in layer II; affected by age, postmortem } \\
\text { delay, pH }\end{array}$ \\
\hline $\begin{array}{l}\text { Bernard et al. } \\
{[48], 2011}\end{array}$ & $\begin{array}{l}\text { Microarray study of gene expression } \\
\text { in LC of postmortem patients with } \\
\text { major depression, BD, and controls; } \\
\text { genes interrogated with ISH }\end{array}$ & $\begin{array}{l}27 \text { postmortem brains: } \\
9 \text { control }(8 \mathrm{M} / 1 \mathrm{~F} ; \mathrm{pH} 6.94 \pm 0.04 ; \\
50.7 \pm 5.6) \\
12 \mathrm{MDD}(11 \mathrm{M} / 1 \mathrm{~F} ; \mathrm{pH} 7.03 \pm 0.04 \text {; age } \\
49.6 \pm 4.2) \\
6 \mathrm{BD}(5 \mathrm{M} / 1 \mathrm{~F} ; \mathrm{pH} 6.95 \pm 0.04 ; \text { age } \\
43.2 \pm 7.4) \\
25 \text { Caucasian, } 1 \text { Pacific Islander, } 1 \\
\text { African-American }\end{array}$ & LC & $\begin{array}{l}\text { Glutamate signaling pathway most significantly altered in } \\
\text { MDD; SLC1A2 (EAAT2) gene expression significantly } \\
\text { decreased in midrostral LC in MDD on microarray and } \\
\text { qRT-PCR; SLC1A3 (EAAT1) gene expression significantly } \\
\text { decreased in midrostral LC in MDD on microarray and } \\
\text { qRT-PCR; SLC1A2 (EAAT2) gene expression not de- } \\
\text { creased to statistical significance on ISH; SLC1A3 (EAAT1) } \\
\text { gene expression significantly decreased on ISH }\end{array}$ \\
\hline
\end{tabular}

\begin{tabular}{|c|c|c|c|c|}
\hline $\begin{array}{l}\text { Murphy et al. } \\
{[58], 2011}\end{array}$ & $\begin{array}{l}\text { Genotyping for SNPs associated } \\
\text { with suicide attempt from blood } \\
\text { samples of } 76 \text { suicide attempters and } \\
83 \text { nonattempters, with a variety of } \\
\text { diagnoses including BD, MDD, SZ, } \\
\text { other psychotic disorders, sub- } \\
\text { stance/alcohol use disorders, anxiety } \\
\text { disorders, and eating disorders }\end{array}$ & $\begin{array}{l}159 \text { blood samples including: } \\
9 \mathrm{BD}(5 \mathrm{SA} / 4 \text { nonattempt) } \\
85 \mathrm{MDD}(48 \mathrm{SA} / 37 \text { nonattempt }) \\
\text { Comorbid diagnoses present for signifi- } \\
\text { cant but unspecified numbers of patients }\end{array}$ & White blood cells & $\begin{array}{l}\text { Suicide attempters significantly younger than nonattempt- } \\
\text { ers across pooled diagnoses; genotypic association analysis } \\
\text { found intronic SNP rs4755404 of SLC1A2 (EAAT2) } \\
\text { significantly associated with SA, with G/C or G/G geno- } \\
\text { type significantly more likely in SA; dominant genotype at } \\
\text { SNP rs4755404 associated with SZ and psychotic disorders } \\
\text { but not BD or MDD; genotypic association analysis found } \\
\text { 3'untranslated region SNP rs2269272 of SLC1A3 (EAAT1) } \\
\text { associated with nonattempters, with T/T genotype more } \\
\text { likely in nonattempters, but not to significance }\end{array}$ \\
\hline $\begin{array}{l}\text { Dallaspezia et al. } \\
{[51], 2012}\end{array}$ & $\begin{array}{l}\text { DNA extracted from whole blood of } \\
110 \text { BD type } 1 \text { patients to examine } \\
\text { effect of SLC1A2 SNP rs } 4354668 \\
(-181 \mathrm{~A}>\mathrm{C}) \text { on glutamate function, } \\
\text { illness recurrence, and effect of } \\
\text { lithium treatment }\end{array}$ & $\begin{array}{l}110 \text { BD type } 1 \text { blood samples: } \\
56 \text { not taking lithium, or not taking for } \geq 6 \\
\text { months } \\
54 \text { taking lithium for } \geq 6 \text { months } \\
\text { All Caucasian, } 76 \mathrm{~F} / 34 \mathrm{M}\end{array}$ & White blood cells & $\begin{array}{l}\text { Allelic frequencies similar to those of general population; } \\
\text { rs4354668 T/T ( } n=37) \text { associated with significantly lower } \\
\text { mood episode frequency; rs } 4354668 \mathrm{G} / \mathrm{G}(n=16 \text {; reduced } \\
\text { EAAT2 transcription) significantly associated with more } \\
\text { manic episodes, greater episode frequency; lithium } \\
\text { treatment countered the G/G polymorphism effect and } \\
\text { reduced recurrence rate }\end{array}$ \\
\hline $\begin{array}{l}\text { Chandley et al. } \\
{[49], 2013}\end{array}$ & $\begin{array}{l}\text { Gene expression analysis of } S L C 1 A 2 \\
\text { in glia of LC of men with MDD }\end{array}$ & $\begin{array}{l}49 \text { postmortem brains: } \\
20 \text { controls ( } 20 \mathrm{M} \text {; pH } 6.59 \pm 0.08 \text {; age } \\
42 \pm 4) \\
19 \mathrm{MDD}(19 \mathrm{M} ; \mathrm{pH} 6.62 \pm .06 \text {; age } 43 \pm 4 \text { ) }\end{array}$ & $\begin{array}{l}\text { Pontine LC; right PFC } \\
\text { (BA10) of subset }\end{array}$ & $\begin{array}{l}\text { Significantly decreased } S L C 1 A 3 \text { (EAAT1) in MDD } \\
\text { homogenized LC than controls; no significant difference in } \\
\text { SLC1A2 (EAAT2) expression between MDD and controls } \\
\text { in homogenized LC; significantly lower SLC1A3 (EAAT1) } \\
\text { in astrocytes of MDD than controls; significantly decreased } \\
\text { SLC1A2 (EAAT2) expression in astrocytes of LC in MDD } \\
\text { compared to control; no significant difference in SLC1A2 } \\
\text { expression in PFC between MDD and controls; insufficient } \\
\text { protein to compare SLC1A3/1A2 gene expression with } \\
\text { EAAT1/2 protein levels }\end{array}$ \\
\hline $\begin{array}{l}\text { Medina et al. } \\
{[55], 2013}\end{array}$ & $\begin{array}{l}\text { In situ hybridization for genes for } \\
\text { EAAT1/2 and VGLUT1 from } \\
\text { hippocampus of patients with MDD } \\
\text { and BD }\end{array}$ & $\begin{array}{l}25 \text { postmortem brains: } \\
11 \text { control (11 M; pH 6.6-7.2; age 40-78) } \\
15 \mathrm{MDD}(13 \mathrm{M} / 2 \mathrm{~F} ; \mathrm{pH} 6.5-7.1 \text {; age } \\
19-72) \\
7 \mathrm{BD}(5 \mathrm{M} / 2 \mathrm{~F} ; \mathrm{pH} 6.5-7.1 ; \text { age } 23-69) \\
\text { All subjects Caucasian }\end{array}$ & Hippocampus & $\begin{array}{l}\text { SLC1A2 (EAAT2) and SLC1A3 (EAAT1) genes significant- } \\
\text { ly downregulated in MDD, nonsignificantly downregulat- } \\
\text { ed in BD; SLC17A7 (VLUT1) gene significantly upregu- } \\
\text { lated in MDD, and nonsignificantly upregulated in BD; } \\
\text { SLC1A2 gene expression significantly downregulated in } \\
\text { MDD but not BD }\end{array}$ \\
\hline
\end{tabular}


Table 2 (continued)

\begin{tabular}{|c|c|c|c|c|}
\hline Reference & Description & Subject characteristics & Tissue examined & Findings \\
\hline $\begin{array}{l}\text { Oh et al. [59], } \\
2014\end{array}$ & $\begin{array}{l}\text { Data-mined neuropathological data } \\
\text { from multiple brain regions in } \\
\text { online dataset from Stanley neuro- } \\
\text { pathology consortium (SNCID) }\end{array}$ & $\begin{array}{l}60 \text { postmortem brains: } \\
15 \mathrm{SZ}(9 \mathrm{M} / 6 \mathrm{~F} ; \mathrm{pH} 5.8-6.6 \text {; age } 25-62 \text {; } \\
13 \mathrm{C} / 2 \mathrm{~A}) \\
15 \mathrm{BD}(9 \mathrm{M} / 6 \mathrm{~F} ; \mathrm{pH} \text { 5.8-6.5; age } 25-61 ; \\
14 \mathrm{C} / 1 \mathrm{AA}) \\
15 \mathrm{MDD} \text { without psychosis }(9 \mathrm{M} / 6 \mathrm{~F} ; \mathrm{pH} \\
5.6-6.5 \text {; age } 30-65 ; 15 \mathrm{C} ; 7 \text { suicides) } \\
15 \text { control }(9 \mathrm{M} / 6 \mathrm{~F} ; \mathrm{pH} 5.8-6.6 \text {; age } \\
29-68 ; 14 \mathrm{C} / 1 \mathrm{AA} ; \\
0 \text { suicides) }\end{array}$ & DLPFC (BA46) & $\begin{array}{l}\text { SLC1A2 mRNA expression significantly decreased in } \\
\text { DLPFC white matter of MDD compared to controls; } \\
\text { SLC1A2 mRNA expression slightly decreased in DLPFC } \\
\text { deep gray matter in MDD compared to controls; lower } \\
\text { SLC1A2 mRNA expression significantly correlated with } \\
\text { decreased GAD1 mRNA expression in MDD but not } \\
\text { controls }\end{array}$ \\
\hline $\begin{array}{l}\text { Poletti et al. [61], } \\
2014\end{array}$ & $\begin{array}{l}\text { Comparing effect of SLC1A2 SNP } \\
\text { rs } 4354668 \text { alleles on hippocampus } \\
\text { gray matter volume in BD patients } \\
\text { exposed to high scores of ACE vs. } \\
\text { low scores }\end{array}$ & $\begin{array}{l}86 \text { BD type } 1 \text { blood samples }(56 \mathrm{~F} / 30 \mathrm{M} \text {; } \\
\text { none on lithium) } \\
43 \text { High ACE (age } 44.18 \pm 11.76) \\
43 \text { Low ACE (age } 46.69 \pm 11.82 \text { ) } \\
\text { MRI imaging of brain for hippocampal } \\
\text { volume }\end{array}$ & White blood cells & $\begin{array}{l}\text { SLC1A2 SNP rs } 4354668 \text { significantly influences gray } \\
\text { matter volume in BD subjects with low ACE scores, with } \\
\text { T/T homozygotes associated with significantly decreased } \\
\text { gray matter volume; SLC1A2 SNP rs } 4354668 \text { alleles made } \\
\text { no differences in high ACE group; high ACE associated } \\
\text { with hippocampal gray matter volume reduction }\end{array}$ \\
\hline $\begin{array}{l}\text { Fiorentino et al. } \\
{[52], 2015}\end{array}$ & $\begin{array}{l}\text { Two data sets from UCL1 and UCL2 } \\
\text { cohorts were screened for SCL1A2 } \\
\text { variants associated with BD and } \\
\text { compared with NHS samples of } \\
\text { patients with SZ and with healthy } \\
\text { European controls }\end{array}$ & $\begin{array}{l}\text { 1,099 BD, } 630 \text { SZ, } 1,095 \text { control: } \\
506 \text { BD1 (UCL1, blood) } \\
593 \text { BD1 or BD2 (UCL2, saliva) } \\
630 \text { SZ (NHS patients, blood) } \\
1,095 \text { control (blood) }\end{array}$ & $\begin{array}{l}\text { Blood } \\
\text { Saliva }\end{array}$ & $\begin{array}{l}\text { No SLC1A2 gene variant associated with BD or SZ; Rare } \\
\text { variants detected only in cases: rs } 145827578: G>A \text { found } \\
\text { only in } 3 \mathrm{BD} \text { and } 2 \text { SZ cases, no controls; rs 199599866:G }>A \\
\text { found in } 1 \mathrm{BD} \text { and } 1 \mathrm{SZ} \text { case, no controls; rs } 4354668: \mathrm{A}>\mathrm{C} \\
\text { failed to replicate association with lithium efficacy; } \\
\text { rs } 4755404: \mathrm{C}>\mathrm{G} \text { failed to replicate association with at- } \\
\text { tempted suicide }\end{array}$ \\
\hline $\begin{array}{l}\text { Poletti et al. [60], } \\
2015\end{array}$ & $\begin{array}{l}\text { Assessed depressed BD type } 1 \\
\text { inpatients for cognitive perfor- } \\
\text { mance; compared results to } \\
\text { rs } 4354668 \text { variants in the EAAT2 } \\
\text { gene promoter, and rs } 2731880 \\
\text { variants in the EAAT1 gene pro- } \\
\text { moter }\end{array}$ & $\begin{array}{l}60 \text { BD type } 1 \text {, depressed, no ECT in } \\
\text { previous } 6 \text { months; no controls }\end{array}$ & White blood cells & $\begin{array}{l}\text { EAAT1 genotype distribution respected Hardy-Weinberg } \\
\text { equilibrium; EAAT2 genotype distribution did not respect } \\
\text { Hardy-Weinberg equilibrium; EAAT1 polymorphisms } \\
\text { were significantly associated with differences in working } \\
\text { memory, verbal fluency, and selective attention; EAAT2 } \\
\text { polymorphisms showed no association with cognitive } \\
\text { functions }\end{array}$ \\
\hline $\begin{array}{l}\text { Medina et al. [56], } \\
2016\end{array}$ & $\begin{array}{l}\text { Hippocampal RNA microarray } \\
\text { analysis in MDD patients vs. } \\
\text { controls }\end{array}$ & $\begin{array}{l}23 \text { postmortem brains: } \\
13 \mathrm{MDD}(13 \mathrm{M} ; \mathrm{pH} 6.5-7.1 \text {; age } 19-65) \\
10 \text { control }(10 \mathrm{M} \text {; pH 6.6-7.2; age } 40-78) \\
\text { All Caucasian }\end{array}$ & Hippocampus & $\begin{array}{l}\text { SLC1A2 (EAAT2) downregulated in MDD compared to } \\
\text { controls; SLC1A3 (EAAT1) downregulated in MDD } \\
\text { compared to controls; AQP4 downregulated in MDD } \\
\text { compared to controls }\end{array}$ \\
\hline $\begin{array}{l}\text { Zhao et al. [63], } \\
2016\end{array}$ & $\begin{array}{l}\text { Comparison of RNA expression of } \\
\text { components of glutamate metabo- } \\
\text { lism in young MDD patients and } \\
\text { controls, and elderly depressed } \\
\text { patients and controls }\end{array}$ & $\begin{array}{l}36 \text { postmortem brains from Stanley } \\
\text { Medical Research Institute (SMRI): } \\
17 \mathrm{MDD}-\mathrm{s}(10 \mathrm{M} / 7 \mathrm{~F} ; 16 \mathrm{C} / 1 \text { Hispanic; } \mathrm{pH} \\
6.36-6.88 \text {; age 24-63) } \\
7 \mathrm{MDD}(3 \mathrm{M} / 4 \mathrm{~F} ; 7 \mathrm{C} \text {; } \mathrm{pH} 6.3-6.9 \text {; age } \\
36-56 \text { ) } \\
12 \text { control ( } 8 \mathrm{M} / 4 \mathrm{~F} \text {; } 11 \mathrm{C} / 1 \text { Hispanic; } \mathrm{pH} \\
6.31-6.91 \text {; age } 24-63) \\
37 \text { postmortem brains from Netherlands } \\
\text { brain bank (NBB): } \\
22 \text { elderly control (pH 5.80-7.39; age } \\
56-96) \\
5 \text { elderly MDD, } 10 \text { BD depressed (pH } \\
6.26-6.82 \text {; age } 45-93)\end{array}$ & $\begin{array}{l}\text { ACC (BA24) } \\
\text { DLPFC (BA46 SMRI; BA9 } \\
\text { NBB) }\end{array}$ & $\begin{array}{l}\text { SMRI (younger patient group): } \\
\text { EAAT1 and EAAT2 gene expression significantly de- } \\
\text { creased in DLPFC of MDD+suicide patients than nonsui- } \\
\text { cidal MDD; EAAT1 and EAAT2 transcript levels signifi- } \\
\text { cantly increased in the DLPFC of nonsuicidal MDD } \\
\text { patients compared to controls; no difference in gene } \\
\text { transcription found between violent and non-violent } \\
\text { suicide methods; no statistically significant differences in } \\
\text { EAAT2 expression in ACC; EAAT1 and EAAT2 gene } \\
\text { expression positively correlated with BDNF gene expres- } \\
\text { sion in MDD+suicide patients } \\
\text { NBB (elderly patient group): } \\
\text { No suicides in this population; no significant differences in } \\
\text { EAAT2 expression in ACC; no significant differences in } \\
\text { EAAT2 expression within depressed group between those } \\
\text { with and without suicidal ideation }\end{array}$ \\
\hline $\begin{array}{l}\text { Jia et al. [53], } \\
2017\end{array}$ & $\begin{array}{l}\text { Examine DNA methylation of } \\
\text { SLC1A2 promoter in BD patients } \\
\text { with and without binge-eating and } \\
\text { substance use disorders }\end{array}$ & $\begin{array}{l}\text { BD type } 1 \text { blood samples: } \\
30 \mathrm{BD}(14 \mathrm{M} / 16 \mathrm{~F} \text {; age } 42.6 \pm 15.4) \\
30 \mathrm{BD}+\text { comorbid } \mathrm{BE}(7 \mathrm{M} / \\
23 \mathrm{~F} \text {; age } 45.2 \pm 14.8) \\
30 \mathrm{BD}+\text { comorbid } \mathrm{ND}(14 \mathrm{M} / \\
16 \mathrm{~F} \text {; age } 35.1 \pm 13.1) \\
30 \mathrm{BD}+\text { comorbid } \mathrm{AA}+\mathrm{ND}(13 \mathrm{M} / 17 \mathrm{~F} \text {; } \\
\text { age } 35.7 \pm 10.4) \\
30 \mathrm{BD}+\text { comorbid AA }(18 \mathrm{M} / \\
12 \mathrm{~F} \text {; age } 39.6 \pm 12.7) \\
32 \text { control }(14 \mathrm{M} / 18 \mathrm{~F} \text {; age } 37.4 \pm 13.4)\end{array}$ & White blood cells & $\begin{array}{l}\text { SLC1A2 promoter region hypermethylated in } \mathrm{BD} \text { without } \\
\text { addictions; SLC1A2 promoter region hypomethylated in } \\
\text { BD with nicotine addiction and binge eating }\end{array}$ \\
\hline
\end{tabular}

A, Asian; AA, African-American; ACC, anterior cingulate cortex; ACE, adverse childhood experiences; AD, alcohol dependence; ANCOVA, analysis of covariance; BA, Brodmann Area; C, Caucasian; BD, bipolar disorder; BD1/2, bipolar disorder type 1 or type 2; DLPFC, dorsolateral prefrontal cortex; GAD1, glutamic acid decarboxylase 1; ISH, in situ hybridization; NHS, National Health Service of the United Kingdom; MDA, major depressive disorder with alcohol dependence; MDD, major depressive disorder; MDD-s, major depressive disorder - died by suicide; LC, locus coeruleus; PFC, prefrontal cortex; qRT-PCR, quantitative real-time polymerase chain reaction; Q-PCR, quantitative real-time polymerase chain reaction; SA, suicide attempt; SZ, schizophrenia; UCL1/2, University College of London Bipolar Affective Disorder genome wide association study cohorts 1 and 2 .

and suggest that a Glt-1 inhibitor cannot reverse despair behavior in a serotonin-depleted or glutamatergically inhibited brain.

Several papers explored the pharmacological modulation of Glt-1 expression in depression models [22, 25, 26, $29-31,35,37,38,44-46]$, including antidepressant agents (fluoxetine, citalopram, escitalopram, ketamine, nortriptyline, and tianeptine) and their effect on Glt-1. In rats, fluoxetine reversed stress-induced depressive behaviors and hippocampal Glt-1 decreases [29]. In mice, fluoxetine improved depressive behaviors even in the presence of DHK-induced Glt-1 inhibition [30] and had no effect 
on hippocampal Glt-1 protein levels [38]. In summary, fluoxetine improved depression-like behaviors in mice and rats, but only normalized hippocampal Glt-1 levels in rats without altering reduced hippocampal Glt-1 levels in mice. Various explanations for differential Glt-1 expression in response to fluoxetine include dose response and acuity (rats received fluoxetine $10 \mathrm{mg}$ daily for 4 weeks [29], while mice received fluoxetine $20 \mathrm{mg} / \mathrm{kg}$ as a single dose [30] or daily for 7 days [38]), or species response differences. In rats, stress increased hippocampal Glt-1a and Glt- $1 \mathrm{~b}$, and the tricyclic antidepressant (tianeptine) prevented Glt-1a increases, but not Glt-1b [25]. There were also marked differences in the effect of antidepressants across mouse strains [37]. In three strains (C57BL/6J, 129S1/SvemJ, FVB/NJ) chronic stress increased Glt-1 mRNA, while the antidepressants escitalopram and nortriptyline decreased Glt-1, but in the fourth strain (DBA/2J) the opposite was demonstrated: stress decreased Glt-1 mRNA, while antidepressants increased it.

Ketamine is used off-label for rapid treatment of depression [69]. In rats, ketamine significantly reversed stress-induced decreases of hippocampal Glt-1 mRNA, decreased stress-induced hippocampal glutamate increases, and reversed depression-like behaviors (spontaneous locomotion, sucrose preference) $[35,46]$. The effect of ketamine on Glt-1 may be modulated through BDNF-TrkB signaling, since the ketamine-induced Glt-1 changes were prevented when rats were pretreated with a TrkB receptor inhibitor [35]. Lithium is a mood stabilizer used in $\mathrm{BD}$ and (without Food and Drug Administration indication) in depression treatment and prophylaxis. In rats with stress-induced increased hippocampal Glt-1 mRNA, lithium prevented both this and loss of dendrite length [26].

Electroconvulsive shock (ECS) is an animal model of electroconvulsive therapy (ECT) which is a clinical treatment for depression in humans. Unlike ECT, however, ECS induces seizures in typically awake animals and therefore is itself a potential stressor. In chronically stressed rats, ECS further downregulated Glt-1, increased hippocampal glutamate, and worsened behavioral markers of depression [45]. The anesthetic agent propofol significantly normalized stress-induced and ECS-induced Glt-1 downregulation, glutamate concentration, and behavior [45].

Icariin is a flavonoid extracted from Horny Goat Weed and used extensively in Chinese traditional medicine, with antidepressant and neuroprotective effects in rodents. In prenatally stressed rats, icariin administered to male offspring reduced stress-elevated group I metabo-

EAAT2 in Bipolar Disorder and Unipolar Depression tropic glutamate receptors (mGluR1/5) mRNA and protein levels, and increased stress-reduced EAAT2 mRNA and protein levels. Zinc or fluoxetine decreased stressinduced depressive behaviors, but neither altered hippocampal Glt-1 levels [38].

\section{Human Studies}

Genetic Findings

Although several studies have analyzed genetic associations of SLC1A2 with mood disorders, no SLC1A2 single nucleotide polymorphism (SNP) has a confirmed diagnostic association with MDD or BD. In the currently available GWAS data from the Psychiatric Genomics Consortium (PGC) no SNP within a $20-\mathrm{kb}$ window of SLC1A2 reaches GWAS significance for MDD [70] or BD [71], or schizophrenia [72] (no association having a p value lower than $5 \times 10^{-4}$ ). It is possible that rare variants may be detected in future sequencing studies, and for now this remains speculative. However, positive genetic correlations have been reported for subphenotypes of mood disorders. For example, minor alleles within SLC1A2 have been associated with the rapid cycling subtype of BD [73]. Additionally, SLC1A3 and SLC1A2 polymorphisms have been studied in mood and psychotic disorders, and found to be associated with differences in cognition, memory, executive function, suicide completion, and medication responses [74, 75]. The effects of 28 SNPs in 18 candidate genes were studied in a mixed population of 159 psychiatric patients including $85 \mathrm{MDD}$ and $9 \mathrm{BD}$ patients [58]. rs4755404 (an SNP in an intronic region of SLC1A2) was significantly associated with suicide attempts. Testing for associations with other clinical variables such as diagnosis, an association with schizophrenia and other psychotic disorders was found in a dominant model, but no effect was seen for MDD or BD, though associations with diagnoses was not the primary focus of the study. A functional SNP, rs4354668 (SLC1A2-181 $A>C$ ), affecting protein expression and plasma glutamate levels [76], was studied for its effect on history of illness in $\mathrm{BD}(n=110)$ [51]. This study found that T/T homozygotes had a significantly lower mood episode frequency, while G/G homozygotes experienced higher mood episode recurrence (depressive, manic, mixed-state) and an increased mania-to-depression ratio. Furthermore, a multivariate analysis revealed an interaction between the genotype and lithium treatment with the effect of the genotype on episode recurrence rate only being present in lithium-untreated patients. The G allele of SNP rs4354668 (within the promoter region of SLC1A2) is associated with decreased EAAT2 activity and increased plasma 
glutamate concentrations [60]. The minor allele $\mathrm{T}$ of rs43534668 was associated with reduced hippocampal gray matter volume, but only in patients with low numbers of adverse childhood experiences (ACEs) [61]. Patients with high ACEs displayed an overall reduction in gray matter volume compared to patients with low ACEs that was not further reduced in subjects with the T allele. Complete histories of psychopharmacological treatments were limited, but lifetime lithium exposure did not alter allelic associations. An association between brain volume and number of mood episodes was not reported. The rs43534668 G allele has been associated with worse cognition (executive function and working memory) in schizophrenia, but this effect was not observed in BD [60].

The largest genetic study of SLC1A2 in BD included $1,099 \mathrm{BD}$ patients and 1,095 controls [52]. Its primary analysis included nonsynonymous variants, intron/exon junction variants, and SNPs in the putative regulatory region, whose minor allele frequency was unknown or $<0.01$. Two recurrent missense variants (rs145827578: $\mathrm{G}>\mathrm{A}, \mathrm{rs} 199599866: \mathrm{G}>\mathrm{A})$ and one recurrent $5^{\prime}$-UTR variant (ss825678885:G>T) were found in BD cases only (3, 1 , and 2, respectively) and not controls; none of the analyzed SNPs reached statistical significance alone. Taking advantage of the large sample size, the authors also tried to replicate previous studies but found no association of rs4755404 with attempted suicide [58] and no association of rs4354668 with lithium efficacy, defined as a reduction in mood episode number [51].

\section{Molecular Differences by Brain Region}

Prefrontal Cortex. The prefrontal cortex (PFC) is an association cortex crucial to human cognition, organizing input from diverse sensory modalities, maintaining attention, working memory, and coordination of goaldirected behaviors. It comprises several Brodmann areas (BA) anterior to primary motor and premotor cortices, responsible for executive functioning (BA9/10/46), language processing (BA44/45), and emotional processing and sociability (BA47/10/11/13) [77]. The PFC has been studied in many psychiatric disorders, with differences found in conditions including autism, schizophrenia, $\mathrm{MDD}$, and BD. Six articles studied EAAT2 expression for this brain region in MDD and $\mathrm{BD}[49,50,57,59,62,63]$. Microarray analysis of gene expression in the dorsolateral PFC (DLPFC: BA9/46) in MDD, BD, and controls found SLC1A2 downregulated in MDD (fold change: $0.71, p<0.05)$ but not in $\mathrm{BD}[50]$. Attempted verification by in situ hybridization (ISH) observed a nonsignificant downward trend. A partial corroboration [59] reported that SLC1A2 expression was significantly reduced in DLPFC white matter (BA46) of MDD compared to controls and found a trend for reduced expression of SLC1A2 in superficial and deep gray matter. However, the differences were very small and the $p$ values were not corrected for multiple testing. Furthermore, the authors report a correlation between GAD1 (glutamate decarboxylase 1) and SLC1A2 gene expression in the deep gray matter of BA46 in MDD but not in controls. No significant results were reported for BD. Adding to gene expression data, EAAT2 protein expression in the left orbitofrontal cortex (BA47) of patients with MDD, MDD + alcoholism (MAD), alcoholism, and controls was examined [57]. Immunohistochemistry found significantly reduced EAAT2 protein levels in MDD and MAD but not in alcoholism alone, when compared with controls. The same trend was observed in Western blot, but the results were not statistically significant. Another study based on microarray analysis of gene expression in DLPFC in BD reported elevated EAAT2 levels after correcting for $\mathrm{pH}$ and age. However, this increase could not be validated by qPCR, with the authors speculating this was due to targeting the wrong region of the gene [62]. In contrast to these findings are reports of no differences in gene expression in homogenized PFC (BA10) between matched MDD and controls [49]. Grouping patients by age and suicide status found young MDD patients without suicide had elevated DLPFC (BA9) EAAT2 levels on qPCR when compared to controls and young MDD suicides [63]. No difference in gene transcription was found between violent and nonviolent suicide methods and no differences were reported between MDD and controls, or between MDD and controls in older patients, even when grouped according to suicidal ideation.

Anterior Cingulate Cortex. The anterior cingulate cortex (ACC) is part of the limbic system and surrounds the anterior part of the corpus callosum, comprising BA24, 32, and 33. It appears to play important roles in both autonomic and higher-level cognitive functions, including pain processing, performance monitoring, value encoding, decision making, emotions, learning, and motivation [78]. The ACC has been heavily studied in psychiatric disorders and has been associated with MDD, schizophrenia, and ADHD. One study described a trend in ACC similar to DLPFC: significant downregulation of SLC1A2 in microarray with a downward trend strongest in layer 2 [50]. In a direct comparison between the two brain regions between all patients and controls, ACC had higher SLC1A2 expression than DLPFC. A separate study found no differences in ACC SLC1A2 levels in MDD compared DOI: $10.1159 / 000501885$
Blacker/Millischer/Webb/Ho/Schalling/ Frye/Veldic 
to controls, nor in any of the other comparisons (young suicidal vs. nonsuicidal vs. controls; older patients vs. controls; older patients with suicidal ideation vs. controls) [63]. However, a weak correlation $(p=0.036)$ between levels of SLC1A2 and TrkB.T1 (the truncated receptor of BDNF) was reported in MDD patients regardless of suicidal ideation.

Locus coeruleus. The locus coeruleus (LC) is the primary site of central nervous system norepinephrine synthesis and is involved in autonomic responses (arousal, sleep/wake cycles, stress response) and higher cognition (attention, memory, perception, motivation) [79]. Differential expression in the midrostral LC of genes involved in glutamate signaling was studied in healthy controls and MDD [48]. SLC1A2 was decreased in microarray and qPCR, but not ISH, with no differences between BD and controls. A separate study of glutamatergic and astrocytic markers in postmortem homogenized pontine LC and microdissected astrocytes/oligodendrocytes found no differences in LC SLC1A2 expression between MDD and controls [49]. However, there was a significant reduction of SLC1A2 in astrocytes $(p<0.001)$ but not oligodendrocytes in MDD compared to controls.

Striatum. The striatum is part of the subcortical basal ganglia and plays an important role in motor and reward systems, including reward cognition, reinforcement, and motivation. It receives glutamatergic and dopaminergic inputs. One study reported no difference in EAAT2 mRNA levels measured by ISH in the ventral striatum, caudate, or putamen between MDD and BD diagnoses [54]. However, EAAT2 mRNA levels were significantly lower in the ventral striatum than in the caudate nucleus and putamen across all diagnoses and controls.

Hippocampus. This brain region is primarily involved in memory formation. A study of microdissected hippocampus in $\mathrm{MDD}, \mathrm{BD}$, and healthy controls found a significant downregulation of EAAT2 in MDD but not BD patients by microarray and ISH [55]. These results were confirmed when measuring samples from the same cohort by qPCR $(p=0.002)$ [56].

\section{Discussion}

EAAT2 may play a role in the etiology and phenotype of mood disorders but the data are still contradictory. Possible mechanisms include preventing glutamate excitotoxicity, regulation of glutamate release, modulating glutamatergic receptor activation, and (as part of a macromolecular complex) intracellular water/ion homeosta-

EAAT2 in Bipolar Disorder and Unipolar Depression sis and energy metabolism. Gross neuronal injury results in a massive release of glutamate [80, 81], activating glutamate receptors and causing an excitotoxic cascade [82]. Excitotoxicity causes injury and death of all three components of the neurovascular unit (neuron, glia, vascular cells) [83], further reducing EAAT2 levels while releasing additional glutamate. Glutamate neurotoxicity as a mechanism in psychiatric disorders remains hypothetical [84] but is already being explored in vivo via magnetic resonance spectroscopy (MRS) [85]. MRS combines glutamate + glutamine (the nonexcitotoxic precursor) as a Glx measurement, and studies have found that MDD is typically associated with decreased Glx, while BD is associated with increased Glx. Such data could be combined with EAAT2 studies to determine whether EAAT2 adapts to glutamate, or whether differential EAAT2 expression shifts the glutamatergic signaling system [86]. Arguably, induced animal models of depression best mimic environmentally induced adjustment disorders in humans and may not reflect the same biological mechanisms as primary mood disorders in human subjects. However, the most common findings in human and animal depression models were decreased EAAT2/Glt-1. A small number of animal studies reported Glt-1 upregulation in response to stress/corticosterone, perhaps reflecting an adaptive Glt-1 response to glutamate neurotoxicity. EAAT2 increases and decreases may reflect different experimental chronic stress duration, time of measurement since last stress exposure (i.e., acute stress response superimposed on chronic stress), and in at least one study, strain-specific differences in glutamatergic systems [37]. MRS studies are scarce in rodents, but comparison of glutamate levels with Glt-1 mRNA/protein levels would help clarify whether Glt-1 function and expression adapt to glutamate fluctuations as hypothesized.

A recent functional brain imaging study uncovered an interaction between SLC1A2 polymorphisms and ACE severity upon axial diffusion (along axonal fiber axis) in white matter tracts of BD patients [87]. This is important evidence for the role of glutamate in brain structural changes in response to stress. If stress and depression are associated with decreased glutamate concentrations, as human MRS studies have suggested, EAAT2/Glt-1 downregulation may be an adaptive glial transcriptional and/ or translational response to reduced synaptic glutamate concentrations and subsequent reduced need for glutamate clearance. Glutamate reduction may be secondary either to absolute decreased glutamate levels (such as recycling back to glutamine and/or reduced glutamate synthesis) or decreased presynaptic glutamate release. An-

Mol Neuropsychiatry 2019;5(suppl 1):44-59 55 
other mechanism of EAAT2/Glt-1 reduction might involve decreased glial fibrillary acidic protein (GFAP), a filament protein within astrocytes associated with EAAT2 cell membrane trafficking [88]. Consistent with this mechanism, elderly depressed and suicide subjects have demonstrated decreased GFAP $[89,90]$.

EAAT2 and AQP4 form a macromolecular complex and co-express with multiple other membrane proteins, as well as mitochondria and glycolytic enzymes [18]. In addition to regulating water and ion homeostasis of the neurovascular unit [91], AQP4 may significantly modulate astrocytic function and adult neurogenesis in depression. It has been previously noted that AQP4 rodent knockouts lose both the fluoxetine-induced antidepressant effect and hippocampus neurogenesis [92] and have greater depressive behaviors in response to chronic corticosterone administration [17]. The co-regulation of EAAT2 and AQP4 in mood disorders needs future investigation.

We found no study that reviewed the effect of antipsychotics on EAAT2 expression in human mood disorders. This is relevant because chronic antipsychotic exposure in primates has been associated with decreased brain volume [93] and decreased glial numbers [94]. Chronic antipsychotics in rodents have been associated with decreased Glt-1 [95], which might be secondary to glial decreases. These data are pertinent to future human studies of EAAT2 in mood disorders, as antipsychotics are clinically used for mood stabilization and as adjunctive therapy of depressive and anxious symptoms.

Individual SNPs are difficult to associate with mood disorders across genetic studies, partly reflecting the complexity of the pathophysiology of these conditions and partly the need for very large samples for adequate power. Human studies have suggested genetic and epigenetic contributions to BD and MDD, including differential expression of the SLC1A2 gene. Our group, for example, has studied epigenetic modifications of $\mathrm{CpG}$ islands in SLC1A2 promoter regions in BD with and without comorbid substance or food addictions [53]. $\mathrm{BD}$ was associated with hypermethylation, while BD + comorbid addictions were associated with hypomethylation, and the effect of addiction on epigenetic modulation of psychiatric disorders remains an area of ongoing research. Human studies have generally reported that MDD is associated with decreased SLC1A2 gene expression in most brain regions, but this has not been replicated in all brain regions, patient cohorts, or cortical layers. One study reported EAAT2 immunostaining was most pronounced in cortical layer II [57], a layer with high intracortical connectivity; the significance of this relationship requires further exploration. Studies have not reported significant associations between $\mathrm{BD}$ and SLC1A2 expression, except one reporting increased SLC1A2 [62]. A difficulty with the human studies reviewed is that they report weak associations and are frequently not corrected for multiple testing. This is especially important in studies of microarray data. Additionally, our systematic process found no studies of gene expression in similar populations/brain regions explicitly reporting negative findings of $S L C 1 A 2$, leading to a potential bias towards positive or false-positive findings.

While unipolar depression seems to be associated with decreased SLC1A2 gene and EAAT2/Glt-1 protein expression, no clear conclusion on the role of EAAT2 in BD can be drawn from the current data, pointing towards varying contributions of EAAT2 to the pathophysiology of different psychiatric disorders. Significant mechanistic questions remain, including the effect of brain regions and regional neural networks, genetic influences on glutamatergic regulation, and glial number. The involvement of EAAT2, not only in preventing excitotoxicity but also as part of a localized macromolecular complex, suggests that EAAT2 may be part of a complicated regulatory system, affecting not just glutamatergic pathways but also glial and neuronal cell homeostasis [96].

\section{Future Perspectives}

An increase in the understanding of the role of EAAT2 in mood disorders is highly warranted. Future studies could include the following areas of research: correlating EAAT2 with glutamatergic markers in vivo, comparing EAAT2 protein/mRNA expression in unipolar depressive disorders during depressive episodes and in remission, and in BD between manic/hypomanic, euthymic, and depressive mood states. Further understanding of the roles of the components of the macromolecular complex may also prove highly beneficial to elucidating roles and mechanisms of action of EAAT2.

\section{Statement of Ethics}

The authors have no ethical conflicts to disclose.

\section{Disclosure Statement}

The authors have no conflicts of interest to declare. DOI: $10.1159 / 000501885$
Blacker/Millischer/Webb/Ho/Schalling/ Frye/Veldic 


\section{Funding Sources}

This research received no specific grant funding from the public, commercial, or not-for-profit sectors.

\section{Author Contributions}

C.J.B. and M.V. conceived and designed the study. C.J.B., L.M.W., V.M., A.M.C.H., and M.V. performed data extraction. C.J.B. and L.M.W. undertook quality analysis. All authors provided critical feedback and participated in analysis and manuscript content. M.S., M.A.F., and M.V. supervised the project.

\section{References}

1 World Health Organisation. Depression and other common mental disorders: global health estimates. Geneva: World Health Organization; 2017. pp. 1-24.

2 Merikangas KR, Jin R, He JP, Kessler RC, Lee $\mathrm{S}$, Sampson NA, et al. Prevalence and correlates of bipolar spectrum disorder in the world mental health survey initiative. Arch Gen Psychiatry. 2011 Mar;68(3):241-51.

3 Abdallah CG, Jiang L, De Feyter HM, Fasula M, Krystal JH, Rothman DL, et al. Glutamate metabolism in major depressive disorder. Am J Psychiatry. 2014 Dec;171(12):1320-7.

4 Blacker CJ, Lewis CP, Frye MA, Veldic M. Metabotropic glutamate receptors as emerging research targets in bipolar disorder. Psychiatry Res. 2017 Nov;257:327-37.

5 Schousboe A. Metabolic signaling in the brain and the role of astrocytes in control of glutamate and GABA neurotransmission. Neurosci Lett. 2019 Jan;689:11-3.

6 Kawahara K, Hosoya R, Sato H, Tanaka M, Nakajima T, Iwabuchi S. Selective blockade of astrocytic glutamate transporter GLT-1 with dihydrokainate prevents neuronal death during ouabain treatment of astrocyte/neuron cocultures. Glia. 2002 Dec;40(3):337-49.

7 Lauriat TL, McInnes LA. EAAT2 regulation and splicing: relevance to psychiatric and neurological disorders. Mol Psychiatry. 2007 Dec;12(12):1065-78.

8 Takahashi K, Foster JB, Lin CL. Glutamate transporter EAAT2: regulation, function, and potential as a therapeutic target for neurological and psychiatric disease. Cell Mol Life Sci. 2015 Sep;72(18):3489-506.

9 Bjørnsen LP, Hadera MG, Zhou Y, Danbolt NC, Sonnewald U. The GLT-1 (EAAT2; slc1a2) glutamate transporter is essential for glutamate homeostasis in the neocortex of the mouse. J Neurochem. 2014 Mar;128(5):641-9.

10 Bjørn-Yoshimoto WE, Underhill SM. The importance of the excitatory amino acid transporter 3 (EAAT3). Neurochem Int. 2016 Sep;98:4-18.

11 Rong X, Tan F, Wu X, Zhang X, Lu L, Zou X, et al. TM4 of the glutamate transporter GLT-1 experiences substrate-induced motion during the transport cycle. Sci Rep. 2016 Oct;6:34522.

12 Yernool D, Boudker O, Jin Y, Gouaux E. Structure of a glutamate transporter homologue from Pyrococcus horikoshii. Nature. 2004 Oct;431(7010):811-8.
13 Leary GP, Stone EF, Holley DC, Kavanaugh MP. The glutamate and chloride permeation pathways are colocalized in individual neuronal glutamate transporter subunits. J Neurosci. 2007 Mar;27(11):2938-42.

$14 \mathrm{Qu}$ S, Kanner BI. Substrates and non-transportable analogues induce structural rearrangements at the extracellular entrance of the glial glutamate transporter GLT-1/EAAT2. J Biol Chem. 2008 Sep;283(39):26391-400.

15 Jiang J, Amara SG. New views of glutamate transporter structure and function: advances and challenges. Neuropharmacology. 2011 Jan;60(1):172-81.

16 Hinson SR, Roemer SF, Lucchinetti CF, Fryer JP, Kryzer TJ, Chamberlain JL, et al. Aquaporin-4-binding autoantibodies in patients with neuromyelitis optica impair glutamate transport by down-regulating EAAT2. J Exp Med. 2008 Oct;205(11):2473-81.

17 Kong H, Zeng XN, Fan Y, Yuan ST, Ge S, Xie WP, et al. Aquaporin- 4 knockout exacerbates corticosterone-induced depression by inhibiting astrocyte function and hippocampal neurogenesis. CNS Neurosci Ther. 2014 May; 20(5):391-402.

18 Wang H, Wang S, Zhang K, Wang H, Lan L, $\mathrm{Ma} X$, et al. Aquaporin 4 Forms a Macromolecular Complex with Glutamate Transporter 1 and $\mathrm{Mu}$ Opioid Receptor in Astrocytes and Participates in Morphine Dependence. J Mol Neurosci. 2017 May;62(1):17-27.

19 Hubbard JA, Szu JI, Yonan JM, Binder DK. Regulation of astrocyte glutamate transporter-1 (GLT1) and aquaporin-4 (AQP4) expression in a model of epilepsy. Exp Neurol. 2016 Sep;283(Pt A):85-96.

20 Meyer T, Münch C, Liebau S, Fromm A, Schwalenstöcker B, Völkel H, et al. Splicing of the glutamate transporter EAAT2: a candidate gene of amyotrophic lateral sclerosis. J Neurol Neurosurg Psychiatry. 1998 Dec;65(6):954.

21 Berger UV, DeSilva TM, Chen W, Rosenberg PA. Cellular and subcellular mRNA localization of glutamate transporter isoforms GLT1a and GLT1b in rat brain by in situ hybridization. J Comp Neurol. 2005 Nov;492(1):78-89.

22 Gourley SL, Espitia JW, Sanacora G, Taylor JR. Antidepressant-like properties of oral riluzole and utility of incentive disengagement models of depression in mice. Psychopharmacology (Berl). 2012 Feb;219(3):805-14.

23 Guan Y, Liu X, Su Y. Ceftriaxone pretreatment reduces the propensity of postpartum depression following stroke during pregnancy in rats. Neurosci Lett. 2016 Oct;632:15-22.
24 Abulseoud OA, Camsari UM, Ruby CL, Kasasbeh A, Choi S, Choi DS. Attenuation of ethanol withdrawal by ceftriaxone-induced upregulation of glutamate transporter EAAT2. Neuropsychopharmacology. 2014 Jun;39(7):1674-84

25 Reagan LP, Rosell DR, Wood GE, Spedding M, Muñoz C, Rothstein J, et al. Chronic restraint stress up-regulates GLT-1 mRNA and protein expression in the rat hippocampus: reversal by tianeptine. Proc Natl Acad Sci USA. 2004 Feb;101(7):2179-84.

26 Wood GE, Young LT, Reagan LP, Chen B, McEwen BS. Stress-induced structural remodeling in hippocampus: prevention by lithium treatment. Proc Natl Acad Sci USA. 2004 Mar;101(11):3973-8.

27 Pines G, Danbolt NC, Bjørås $M$, Zhang $Y$, Bendahan A, Eide L, et al. Cloning and expression of a rat brain L-glutamate transporter. Nature. 1992 Dec;360(6403):464-7.

28 Bechtholt-Gompf AJ, Walther HV, Adams MA, Carlezon WA Jr, Ongür D, Cohen BM. Blockade of astrocytic glutamate uptake in rats induces signs of anhedonia and impaired spatial memory. Neuropsychopharmacology. 2010 Sep;35(10):2049-59.

29 Chen JX, Yao LH, Xu BB, Qian K, Wang HL, Liu ZC, et al. Glutamate transporter 1-mediated antidepressant-like effect in a rat model of chronic unpredictable stress. J Huazhong Univ Sci Technolog Med Sci. 2014 Dec;34(6): $838-44$.

30 Cui W, Mizukami H, Yanagisawa M, Aida T, Nomura M, Isomura Y, et al. Glial dysfunction in the mouse habenula causes depressivelike behaviors and sleep disturbance. J Neurosci. 2014 Dec;34(49):16273-85.

31 Gasull-Camós J, Tarrés-Gatius M, Artigas F, Castañé A. Glial GLT-1 blockade in infralimbic cortex as a new strategy to evoke rapid antidepressant-like effects in rats. Transl Psychiatry. 2017 Feb;7(2 e1038):e1038. ; Epub.

32 Gómez-Galán M, Femenía T, Åberg E, Graae L, Van Eeckhaut A, Smolders I, et al. Running Opposes the Effects of Social Isolation on Synaptic Plasticity and Transmission in a Rat Model of Depression. PLoS One. 2016 Oct; 11(10):e0165071.

33 John CS, Sypek EI, Carlezon WA, Cohen BM, Öngür D, Bechtholt AJ. Blockade of the GLT1 Transporter in the Central Nucleus of the Amygdala Induces both Anxiety and Depressive-Like Symptoms. Neuropsychopharmacology. 2015 Jun;40(7):1700-8. 
34 Kang S, Li J, Bekker A, Ye JH. Rescue of glutamate transport in the lateral habenula alleviates depression- and anxiety-like behaviors in ethanol-withdrawn rats. Neuropharmacology. 2018 Feb;129:47-56.

35 Liu WX, Wang J, Xie ZM, Xu N, Zhang GF, Jia $M$, et al. Regulation of glutamate transporter 1 via BDNF-TrkB signaling plays a role in the anti-apoptotic and antidepressant effects of ketamine in chronic unpredictable stress model of depression. Psychopharmacology (Berl). 2016a Feb;233(3): 405-15.

36 Liu X, Guo H, Sayed MD, Lu Y, Yang T, Zhou $\mathrm{D}$, et al. cAMP/PKA/CREB/GLT1 signaling involved in the antidepressant-like effects of phosphodiesterase 4D inhibitor (GEBR-7b) in rats. Neuropsychiatr Dis Treat. 2016b Jan; 12:219-27.

37 Malki K, Lourdusamy A, Binder E, Payá-Cano J, Sluyter F, Craig I, et al. Antidepressantdependent mRNA changes in mouse associated with hippocampal neurogenesis in a mouse model of depression. Pharmacogenet Genomics. 2012 Nov;22(11):765-76.

38 Manosso LM, Moretti M, Colla AR, Ribeiro CM, Dal-Cim T, Tasca CI, et al. Involvement of glutamatergic neurotransmission in the antidepressant-like effect of zinc in the chronic unpredictable stress model of depression. J Neural Transm (Vienna). 2016 Mar;123(3): $339-52$.

39 Martisova E, Solas M, Horrillo I, Ortega JE, Meana JJ, Tordera RM, et al. Long lasting effects of early-life stress on glutamatergic/GABAergic circuitry in the rat hippocampus. Neuropharmacology. 2012 Apr; 62(5-6): 1944-53.

40 Rappeneau V, Blaker A, Petro JR, Yamamoto BK, Shimamoto A. Disruption of the Glutamate-Glutamine Cycle Involving Astrocytes in an Animal Model of Depression for Males and Females. Front Behav Neurosci. 2016 Dec;10:231

41 Réus GZ, Abaleira HM, Michels M, Tomaz DB, dos Santos MA, Carlessi AS, et al. Anxious phenotypes plus environmental stressors are related to brain DNA damage and changes in NMDA receptor subunits and glutamate uptake. Mutat Res. 2015 Feb;772:30-7.

42 Veeraiah P, Noronha JM, Maitra S, Bagga P, Khandelwal N, Chakravarty S, et al. Dysfunctional glutamatergic and $\gamma$-aminobutyric acidergic activities in prefrontal cortex of mice in social defeat model of depression. Biol Psychiatry. 2014 Aug;76(3):231-8.

43 Zhang XH, Jia N, Zhao XY, Tang GK, Guan LX, Wang D, et al. Involvement of pGluR1, EAAT2 and EAAT3 in offspring depression induced by prenatal stress. Neuroscience. 2013 Oct;250:333-41.

44 Zhang X, Sun H, Su Q, Lin T, Zhang H, Zhang $\mathrm{J}$, et al. Antidepressant-like activity of icariin mediated by group I mGluRs in prenatally stressed offspring. Brain Dev. 2017 Aug; 39(7):593-600.
45 Zhu X, Hao X, Luo J, Min S, Xie F, Zhang F. Propofol inhibits inflammatory cytokine-mediated glutamate uptake dysfunction to alleviate learning/memory impairment in depressed rats undergoing electroconvulsive shock. Brain Res. 2015 Jan;1595:101-9.

46 Zhu X, Ye G, Wang Z, Luo J, Hao X. Sub-anesthetic doses of ketamine exert antidepressant-like effects and upregulate the expression of glutamate transporters in the hippocampus of rats. Neurosci Lett. 2017 Feb;639: 132-7.

47 Zink M, Vollmayr B, Gebicke-Haerter PJ, Henn FA. Reduced expression of glutamate transporters vGluT1, EAAT2 and EAAT4 in learned helpless rats, an animal model of depression. Neuropharmacology. 2010 Feb; 58(2):465-73.

48 Bernard R, Kerman IA, Thompson RC, Jones EG, Bunney WE, Barchas JD, et al. Altered expression of glutamate signaling, growth factor, and glia genes in the locus coeruleus of patients with major depression. Mol Psychiatry. 2011 Jun;16(6):634-46.

49 Chandley MJ, Szebeni K, Szebeni A, Crawford J, Stockmeier CA, Turecki G, et al. Gene expression deficits in pontine locus coeruleus astrocytes in men with major depressive disorder. J Psychiatry Neurosci. 2013 Jul;38(4):276-84.

50 Choudary PV, Molnar M, Evans SJ, Tomita $\mathrm{H}, \mathrm{Li}$ JZ, Vawter MP, et al. Altered cortical glutamatergic and GABAergic signal transmission with glial involvement in depression. Proc Natl Acad Sci USA. 2005 Oct;102(43): 15653-8.

51 Dallaspezia S, Poletti S, Lorenzi C, Pirovano $\mathrm{A}$, Colombo C, Benedetti F. Influence of an interaction between lithium salts and a functional polymorphism in SLC1A2 on the history of illness in bipolar disorder. Mol Diagn Ther. 2012 Oct; 16(5):303-9.

52 Fiorentino A, Sharp SI, McQuillin A. Association of rare variation in the glutamate receptor gene SLC1A2 with susceptibility to bipolar disorder and schizophrenia. Eur J Hum Genet. 2015 Sep;23(9):1200-6.

53 Jia YF, Choi Y, Ayers-Ringler JR, Biernacka JM, Geske JR, Lindberg DR, et al. Differential SLC1A2 promoter methylation in bipolar disorder with or without addiction. Front Cell Neurosci. 2017 Jul;11:217.

54 McCullumsmith RE, Meador-Woodruff JH. Striatal excitatory amino acid transporter transcript expression in schizophrenia, bipolar disorder, and major depressive disorder. Neuropsychopharmacology. 2002 Mar;26(3): 368-75.

55 Medina A, Burke S, Thompson RC, Bunney W Jr, Myers RM, Schatzberg A, et al. Glutamate transporters: a key piece in the glutamate puzzle of major depressive disorder. J Psychiatr Res. 2013 Sep;47(9):1150-6.

56 Medina A, Watson SJ, Bunney W Jr, Myers RM, Schatzberg A, Barchas J, et al. Evidence for alterations of the glial syncytial function in major depressive disorder. J Psychiatr Res. 2016 Jan;72:15-21.
57 Miguel-Hidalgo JJ, Waltzer R, Whittom AA, Austin MC, Rajkowska G, Stockmeier CA. Glial and glutamatergic markers in depression, alcoholism, and their comorbidity. J Affect Disord. 2010 Dec;127(1-3):230-40.

58 Murphy TM, Ryan M, Foster T, Kelly C, McClelland R, O'Grady J, et al. Risk and protective genetic variants in suicidal behaviour: association with SLC1A2, SLC1A3, 5-HTR1B \&NTRK2 polymorphisms. Behav Brain Funct. 2011 Jun;7:22.

59 Oh DH, Oh D, Son H, Webster MJ, Weickert CS, Kim SH. An association between the reduced levels of SLC1A2 and GAD1 in the dorsolateral prefrontal cortex in major depressive disorder: possible involvement of an attenuated RAF/MEK/ERK signaling pathway. J Neural Transm (Vienna). 2014 Jul;121(7):783-92.

60 Poletti S, Locatelli C, Pirovano A, Colombo C, Benedetti F. Glutamate EAAT1 transporter genetic variants influence cognitive deficits in bipolar disorder. Psychiatry Res. 2015 Mar; 226(1):407-8.

61 Poletti S, Locatelli C, Radaelli D, Lorenzi C, Smeraldi E, Colombo C, et al. Effect of early stress on hippocampal gray matter is influenced by a functional polymorphism in EAAT2 in bipolar disorder. Prog Neuropsychopharmacol Biol Psychiatry. 2014 Jun;51:146-52.

62 Shao L, Vawter MP. Shared gene expression alterations in schizophrenia and bipolar disorder. Biol Psychiatry. 2008 Jul;64(2):89-97.

63 Zhao J, Verwer RW, van Wamelen DJ, Qi XR, Gao SF, Lucassen PJ, et al. Prefrontal changes in the glutamate-glutamine cycle and neuro$\mathrm{nal} /$ glial glutamate transporters in depression with and without suicide. J Psychiatr Res. 2016 Nov; $82: 8-15$.

64 du Prel JB, Röhrig B, Blettner M. Critical appraisal of scientific articles: part 1 of a series on evaluation of scientific publications. Dtsch Arztebl Int. 2009 Feb;106(7):100-5.

65 Henn FA, Vollmayr B. Stress models of depression: forming genetically vulnerable strains. Neurosci Biobehav Rev. 2005;29(4-5):799-804.

66 Popoli M, Yan Z, McEwen BS, Sanacora G. The stressed synapse: the impact of stress and glucocorticoids on glutamate transmission. Nat Rev Neurosci. 2011 Nov;13(1):22-37.

67 Behan ÁT, van den Hove DL, Mueller L, Jetten MJ, Steinbusch HW, Cotter DR, et al. Evidence of female-specific glial deficits in the hippocampus in a mouse model of prenatal stress. Eur Neuropsychopharmacol. 2011 Jan; 21(1):71-9.

68 Laschet J, Grisar T, Bureau M, Guillaume D. Characteristics of putrescine uptake and subsequent GABA formation in primary cultured astrocytes from normal C57BL/6J and epileptic DBA/2J mouse brain cortices. Neuroscience. 1992;48(1):151-7.

69 Bobo WV, Vande Voort JL, Croarkin PE, Leung JG, Tye SJ, Frye MA. Ketamine for Treatment-Resistant Unipolar and Bipolar Major Depression: Critical Review and Implications for Clinical Practice. Depress Anxiety. 2016 Aug;33(8):698-710. 
70 Wray NR, Ripke S, Mattheisen M, Trzaskowski M, Byrne EM, Abdellaoui A, et al.; Major Depressive Disorder Working Group of the Psychiatric Genomics Consortium. Genomewide association analyses identify 44 risk variants and refine the genetic architecture of major depression. Nat Genet. 2018 May;50(5): 668-81.

71 Stahl EA, Breen G, Forstner AJ, McQuillin A, Ripke S, Trubetskoy V, et al.; eQTLGen Consortium; BIOS Consortium; Bipolar Disorder Working Group of the Psychiatric Genomics Consortium. Genome-wide association study identifies 30 loci associated with bipolar disorder. Nat Genet. 2019 May;51(5):793-803.

72 Ruderfer DM, Ripke S, McQuillin A, Boocock J, Stahl EA, Pavlides JM, et al.; Bipolar Disorder and Schizophrenia Working Group of the Psychiatric Genomics Consortium. Electronic address: douglas.ruderfer@vanderbilt.edu; Bipolar Disorder and Schizophrenia Working Group of the Psychiatric Genomics Consortium. Genomic Dissection of Bipolar Disorder and Schizophrenia, Including 28 Subphenotypes. Cell. 2018 Jun;173(7):1705-15.e16.

73 Veldic M, Millischer V, Port JD, Ho AM, Jia YF, Geske JR, et al. Genetic variant in SLC1A2 is associated with elevated anterior cingulate cortex glutamate and lifetime history of rapid cycling. Transl Psychiatry. 2019 May;9(1): 149.

74 de Sousa RT, Loch AA, Carvalho AF, Brunoni AR, Haddad MR, Henter ID, et al. Genetic Studies on the Tripartite Glutamate Synapse in the Pathophysiology and Therapeutics of Mood Disorders. Neuropsychopharmacology. 2017 Mar;42(4):787-800.

75 Parkin GM, Udawela M, Gibbons A, Dean B. Glutamate transporters, EAAT1 and EAAT2, are potentially important in the pathophysiology and treatment of schizophrenia and affective disorders. World J Psychiatry. 2018 Jun; $8(2): 51-63$

76 Mallolas J, Hurtado O, Castellanos M, Blanco M, Sobrino T, Serena J, et al. A polymorphism in the EAAT2 promoter is associated with higher glutamate concentrations and higher frequency of progressing stroke. J Exp Med. 2006 Mar;203(3):711-7.
77 Teffer K, Semendeferi K. Human prefrontal cortex: evolution, development, and pathology. Prog Brain Res. 2012;195:191-218.

78 Shenhav A, Botvinick MM, Cohen JD. The expected value of control: an integrative theory of anterior cingulate cortex function. Neuron. 2013 Jul;79(2):217-40.

79 Mai J, Paxinos G, editors. The human nervous system. 3rd ed. San Diego: Academic Press; 2012.

80 Castillo J, Loza MI, Mirelman D, Brea J, Blanco M, Sobrino T, et al. A novel mechanism of neuroprotection: blood glutamate grabber. J Cereb Blood Flow Metab. 2016 Feb;36(2): 292-301.

81 Rao VL, Başkaya MK, Doğan A, Rothstein JD, Dempsey RJ. Traumatic brain injury downregulates glial glutamate transporter (GLT-1 and GLAST) proteins in rat brain. J Neurochem. 1998 May;70(5):2020-7.

82 Lai TW, Zhang S, Wang YT. Excitotoxicity and stroke: identifying novel targets for neuroprotection. Prog Neurobiol. 2014 Apr;115: 157-88.

83 Terasaki Y, Liu Y, Hayakawa K, Pham LD, Lo $\mathrm{EH}$, Ji X, et al. Mechanisms of neurovascular dysfunction in acute ischemic brain. Curr Med Chem. 2014;21(18):2035-42.

84 Plitman E, Nakajima S, de la Fuente-Sandoval C, Gerretsen P, Chakravarty MM, Kobylianskii J, et al. Glutamate-mediated excitotoxicity in schizophrenia: a review. Eur Neuropsychopharmacol. 2014 Oct;24(10):1591-605.

85 Plitman E, de la Fuente-Sandoval C, ReyesMadrigal F, Chavez S, Gómez-Cruz G, LeónOrtiz P, et al. Elevated Myo-Inositol, Choline, and Glutamate Levels in the Associative Striatum of Antipsychotic-Naive Patients With First-Episode Psychosis: A Proton Magnetic Resonance Spectroscopy Study With Implications for Glial Dysfunction. Schizophr Bull. 2016 Mar;42(2):415-24

86 Yüksel C, Öngür D. Magnetic resonance spectroscopy studies of glutamate-related abnormalities in mood disorders. Biol Psychiatry. 2010 Nov;68(9):785-94.

87 Poletti S, Bollettini I, Lorenzi C, Vitali A, Brioschi S, Serretti A, et al. White Matter Microstructure in Bipolar Disorder Is Influenced by the Interaction between a Glutamate Transporter EAAT1 Gene Variant and Early Stress. Mol Neurobiol. 2019 Jan;56(1):702-10.
88 Hughes EG, Maguire JL, McMinn MT, Scholz RE, Sutherland ML. Loss of glial fibrillary acidic protein results in decreased glutamate transport and inhibition of PKA-induced EAAT2 cell surface trafficking. Brain Res Mol Brain Res. 2004 May; 124(2):114-23.

89 Davis S, Thomas A, Perry R, Oakley A, Kalaria RN, O’Brien JT. Glial fibrillary acidic protein in late life major depressive disorder: an immunocytochemical study. J Neurol Neurosurg Psychiatry. 2002 Nov;73(5):55660.

90 Torres-Platas SG, Nagy C, Wakid M, Turecki G, Mechawar N. Glial fibrillary acidic protein is differentially expressed across cortical and subcortical regions in healthy brains and downregulated in the thalamus and caudate nucleus of depressed suicides. Mol Psychiatry. 2016 Apr;21(4):509-15.

91 Rajkowska G, Stockmeier CA. Astrocyte pathology in major depressive disorder: insights from human postmortem brain tissue. Curr Drug Targets. 2013 Oct;14(11):1225-36.

92 Kong H, Sha LL, Fan Y, Xiao M, Ding JH, Wu $\mathrm{J}$, et al. Requirement of AQP4 for antidepressive efficiency of fluoxetine: implication in adult hippocampal neurogenesis. Neuropsychopharmacology. 2009 Apr;34(5):1263-76.

93 Dorph-Petersen KA, Pierri JN, Perel JM, Sun $Z$, Sampson AR, Lewis DA. The influence of chronic exposure to antipsychotic medications on brain size before and after tissue fixation: a comparison of haloperidol and olanzapine in macaque monkeys. Neuropsychopharmacology. 2005 Sep;30(9):1649-61

94 Konopaske GT, Dorph-Petersen KA, Sweet RA, Pierri JN, Zhang W, Sampson AR, et al. Effect of chronic antipsychotic exposure on astrocyte and oligodendrocyte numbers in macaque monkeys. Biol Psychiatry. 2008 Apr; 63(8):759-65.

95 Schneider JS, Wade T, Lidsky TI. Chronic neuroleptic treatment alters expression of glial glutamate transporter GLT-1 mRNA in the striatum. Neuroreport. 1998 Jan;9(1):133-6.

96 O’Donovan SM, Sullivan CR, McCullumsmith RE. The role of glutamate transporters in the pathophysiology of neuropsychiatric disorders. NPJ Schizophr. 2017 Sep;3(1):32. 